\title{
Energy Factors, Leasing Structure and the Market Price of Office Buildings in the U.S.*
}

\author{
Dwight Jaffeeł Richard Stantonªnd Nancy Wallace ${ }^{\S}$
}

August 31, 2011

\begin{abstract}
This paper presents an empirical analysis of the relationship between energy factor markets, leasing structures and the transaction prices of office buildings in the U.S. We employ a large sample of 15,133 office building transactions that occurred between 2001 and 2010. In addition to building characteristics, we also include information on the operating expenses, the net operating income, and the market capitalization rates at sale to estimate an asset pricing model for commercial office real estate assets. A further set of important controls in our analysis is the one-to-twelve month forward contract prices and the shape of the forward contract price curve, using auction data for the regional electricity trading hubs in which the building is located and auction data from the Henry Hub for natural gas. We also include weather metrics in the form of the variance in the last twelve months of minimum and maximum temperature and precipitation for each building's location and sale date. Our final set of controls includes information on the dominant contractual leasing structure of the buildings. Our empirical results suggest that Energy Star labels do not explain additional variance in property prices once the key asset pricing factors of expenses, income and market capitalization rates are included. Energy factor market prices, the shape of the energy forward price curves, and weather metrics are consistently shown to be statistically significant determinants of office building transaction prices, suggesting that commercial office building prices are likely to be exposed to shocks in these markets.
\end{abstract}

${ }^{*}$ This work was supported by the Assistant Secretary for Energy Efficiency and Renewable Energy, Building Technologies Program, of the U.S. Department of Energy under Contract No. DE-AC02-05CH11231.

${ }^{\dagger}$ Haas School of Business, U.C. Berkeley, jaffee@haas.berkeley.edu

${ }^{\ddagger}$ Haas School of Business, U.C. Berkeley, stanton@haas.berkeley.edu.

$\S$ Haas School of Business, U.C. Berkeley, wallace@haas.berkeley.edu. 


\section{Disclaimer}

This document was prepared as an account of work sponsored by the United States Government. While this document is believed to contain correct information, neither the United States Government nor any agency thereof, nor The Regents of the University of California, nor any of their employees, makes any warranty, express or implied, or assumes any legal responsibility for the accuracy, completeness, or usefulness of any information, apparatus, product, or process disclosed, or represents that its use would not infringe privately owned rights. Reference herein to any specific commercial product, process, or service by its trade name, trademark, manufacturer, or otherwise, does not necessarily constitute or imply its endorsement, recommendation, or favoring by the United States Government or any agency thereof, or The Regents of the University of California. The views and opinions of authors expressed herein do not necessarily state or reflect those of the United States Government or any agency thereof or The Regents of the University of California. 


\section{Contents}

1 Introduction $\quad 1$

2 Commercial Office Building Market Value 4

3 The CoStar Data $\quad 6$

3.1 Energy Star Matching . . . . . . . . . . . . . . . . . 8

3.2 Local Weather Data Matching . . . . . . . . . . . . . . . . 9

3.3 Energy Auction Data Matching . . . . . . . . . . . . . . . . 9

3.4 Summary Statistics for the CoStar Transaction Data . . . . . . . . . . . . 11

4 The Investor's Energy Star Rating Decision $\quad 16$

5 Empirical Results with Transactions Prices $\quad 20$

6 Leases 25

6.1 Lease Contracts and Energy Efficient: Economic Theory . . . . . . . . . . 28

6.1.1 Contract Theory, Uncertainty, and Energy Use . . . . . . . . . . . . 28

6.1.2 Capital Investments Under Alternative Lease Contracts . . . . . . . . 30

6.2 Empirical Tests . . . . . . . . . . . . . . . . . . . 32

7 Conclusions $\quad 35$

$\begin{array}{ll}\text { A Appendix } & 36\end{array}$

A.1 Geographic Structure of the Transactions Data . . . . . . . . . . . . . 36

A.2 Weather Data Construction . . . . . . . . . . . . . . 36

A.3 Energy Data Construction . . . . . . . . . . . . . . . . 36

A.3.1 Forward Market for Power (Electricity) . . . . . . . . . . . . . . . 37

A.3.2 Dataset - Platts-Ice Forward Curve . . . . . . . . . . . . . . . . . . 39

A.3.3 Futures Market for Natural Gas . . . . . . . . . . . . . . . . . . 41 


\section{Introduction}

In the United States, buildings consume almost 39\% of the total energy consumption, making real estate the largest energy consuming sector by a considerable margin. By comparison as shown in Table 1, U.S. industrial consumption of energy is about $33 \%$ of the total and the transportation share is about $28 \%$ of the total. Within the real estate sector, the share of total energy used is almost equally split between residential (20.9\%) and commercial (18.0\%) buildings.

Table 1: Buildings Share of U.S. Primary Energy Consumption (Percent), 2006

\begin{tabular}{lllllll}
\hline $\begin{array}{l}\text { Residential } \\
\text { Buildings }\end{array}$ & $\begin{array}{l}\text { Commercial } \\
\text { Buildings }\end{array}$ & $\begin{array}{l}\text { Total } \\
\text { Buildings }\end{array}$ & Industry & Transportation Total & $\begin{array}{l}\text { Total } \\
\text { Consumption } \\
\text { (quads) }\end{array}$ \\
\hline $20.9 \%$ & $18.0 \%$ & $38.9 \%$ & $32.7 \%$ & $28.4 \%$ & $100 \%$ & 99.5 \\
\hline
\end{tabular}

Source: U.S. Department of Energy (2009)

An additional sobering fact is that the energy consumption of U.S. real estate appears, to be substantially less efficient than comparable European buildings, even after controlling for such factors such as climate, GDP, and population. ${ }^{1}$ There is no mystery as to the reason: U.S. costs for electricity and heating oil range from 50 to 75 percent of the levels in most European countries (see ?). This indicates there must be feasible technologies that would allow the energy consumption of U.S. buildings to be reduced significantly. Such investments could arise as the result of building codes and comparable requirements, or as a voluntary response to high and volatile energy prices.

Most economists would agree that the "first-best" solution to reducing U.S. energy consumption, across the three major uses of real estate, industry, and transportation, is to raise the U.S. price of energy through appropriate fiscal instruments. While this may occur in the future, the timing of this change in policy remains highly uncertain. So it is sensible, even critical, to look for alternative, accelerated, mechanisms to reduce U.S. energy consumption. Indeed, if and when U.S. energy prices do rise, the economic adjustment will be easier and faster if the transformation toward a more energy efficient technology is already well along. Facing inadequate energy-efficient investments in real estate, governments in both the U.S. and Europe have intervened to provide additional incentives. To date, three

\footnotetext{
${ }^{1}$ Two reports by the International Energy Agency (see ??) provide comparisons of residential energy use in the U.S. and Europe corrected for climate and measured per unit of GDP or per capital. ? also shows substantially higher U.S. energy consumption compared to Europe after controlling for GDP and population. ? provides a discussion comparing energy use in the U.S., Australia and the European Union.
} 
approaches have dominated theses interventions: expanded building codes, energy-efficiency certifications, and direct fiscal subsidies.

Expanded building codes have been the primary mechanism to ensure energy-efficient structures in Europe and are likely to expand over time in the U.S. as well. Building code requirements, however, have their primary impact on new construction, and given the long durability of most buildings, new construction annually represents a very small percentage of the existing building inventory. Most building codes, furthermore, are prescriptive rather than performance-based, which limits the incentive they provide for new innovative solutions.

Disclosure certificates at the time of building sales have also become an important mechanism in Europe. The 2002 EU Energy Performance in Buildings Directive requires an energy performance certificate based on either the building's design or usage characteristics. While such disclosures might well have an impact on the sales prices, it is unclear to what extent such disclosures motivate either the seller or buyer to initiate energy efficient investments. In the U.S., certifications such as Leeds and Energy Star are available, and such certifications are sought by builders and developers who are planning to create energy efficient buildings. But these certifications primarily apply to new buildings, and it is unclear to what extent the certifications are the factor actually motivating energy-efficiency in these buildings. ${ }^{2}$

Direct subsidies provided by either government agencies and public utilities may provide economic stimulus to energy efficient investments. In these times of harsh fiscal budgets, however, direct subsidies are unlikely to be a major driver of new energy-efficient investments.

Given the limitations of building code requirements, energy-efficiency certifications, and direct subsidies, it is critical to consider whether there are other solutions to the private market failures that are contributing to the under-investment in U.S. building energy efficiency. It is possible, of course, that the available technology is just not profitable in net present value (NPV) terms. However, it appears that NPV positive energy-efficient investment opportunities already exist, and that further innovations and cost-savings from scale economies are literally in process.

In this paper, we focus on the relationship between energy efficiency and commercial office building transaction values. Our analysis is based on a comprehensive data set of commercial office building transactions. The data set was developed to include a rich set of controls for heterogenous building characteristics such as each building's capacity, quality, utilization, and lease contract structure and matched building-specific market information such as the

${ }^{2} ?$ show that buildings with certifications obtain higher sales prices, which provides a motivation for obtaining such certifications. However, it is unclear whether the existence of the certifications motivates energy efficient investments that otherwise would not have been carried out. The existence of higher sales prices on certified buildings also does not indicate whether the initial energy-efficiency investments were NPV positive; to show that, the investments costs must be compared with the sales prices. 
actual capitalization rate at sale, local-level wholesale energy market price dynamics and local weather pattern dynamics at the time of sale. Our goal is determine whether there exists a statistically significant empirical relationship between the energy performance of commercial office buildings and their transaction values controlling for market and building characteristics.

Our sample includes office buildings found in the CoStar data that were located in U.S. office markets with 150,000 or more employees working in the employment category Information, Finance, and Professional and Business Services (the major office categories). ${ }^{3}$ We developed time and market-specific local weather station data and energy forward contract auction data from the trading hubs appropriate to each building and linked these data to each useable transaction record in the CoStar data. Our transaction data set is comprised of office building sales between 2001 and 2010. The data set includes 15,133 arms-length ${ }^{4}$ transactions for office buildings located in 43 U.S. metropolitan areas. Importantly these data are suitable to analyze the relationship between the market transaction values of U.S. office buildings and their structural, contractual, energy and market-related characteristics.

A second objective of the paper is to determine whether U.S. Environmental Protection Agency (EPA), Energy Star Certification, certification that a building operates in the top quartile of energy efficiency in the U.S., affects transaction values. To meet this objective, we obtained information on the population of Energy Star rated buildings from the EPA. The EPA list included the exact location of the building, the numeric Energy Star rating, and the date at which the rating was granted. These data were then merged with the CoStar transaction data so that we can identify all buildings that had an Energy Star rating prior to their sale date. Finally, for a subset of the transactions we have complete information on each building's total operating expense, gross and net operating income, and capitalization rate at the sale date along with information on the first and second mortgage debt structure.

This paper is the first product in a research program that is designed to develop foundational relationships between real estate asset prices, real estate energy consumption, and the energy efficiency price risk exposure of commercial real estate in the U.S. Our goal in this paper is to establish the link between commercial real estate asset prices, operating expenses, and energy factor market inputs. In a companion paper, we seek to establish the link between the energy risk exposure of a building and the valuation of commercial real estate mortgages that also share this risk exposure. The two parts of this research program are needed to develop suitable valuation technologies to underwrite the energy efficiency risk

\footnotetext{
${ }^{3}$ Bureau of Labor Statistics, Employment Hours and Earnings, State and Metro Area, http://www.bls . gov/sae/data.htm.

${ }^{4}$ These are sales between unrelated persons
} 
of commercial real estate mortgages. Energy risk pricing technology for commercial real estate mortgage valuation is also needed to allow for the development of new bond markets to support the capital requirements for energy efficiency retrofits in the U.S. Finally, this work should provide better risk metrics for the existing commercial real estate mortgage market that currently does not underwrite/or price the energy components of commercial real estate mortgage default risk.

The paper is organized into seven sections. In the next section, Section 2, we discuss empirical representations for the value of commercial real estate. In Section 3, we provide details on the construction of our data sets. In Section 4, we conduct an empirical investigation of the Energy Star rating decision of investors in commercial real estate in the U.S. Section 5 presents empirical results for tests on the relationship between real estate transaction prices, operating expenses, net operating income, the capitalization rate, and Energy Star labels. Section 6 considers the role of leasing structure on the pricing of commercial real estate assets and the contractual management of energy price passthroughs to tenants. Section 7 concludes.

\section{Commercial Office Building Market Value}

The canonical representation for the market value of a commercial real estate asset is as the discounted present value of the asset's future net operating income. Since well maintained

office properties typically can be assumed to be long-lived assets, the market price of a commercial office building at the investor's purchase date $(t=0)$ can be written as

$$
P_{0}=\sum_{t=1}^{\infty} \frac{R_{t}}{\left(1+i_{t}\right)^{t}}
$$

where $P_{0}$ is the market price at the investment date, $t=0, R_{t}$ is the net operating income at the $t^{t h}$ period. The forward path of the net operating income is defined as the forward path of gross effective income (rent per square foot times the square footage rented minus the vacancy rate) minus the forward path of the total operating expenses. The market interest rate, $i_{t}$, at the $t^{t h}$ period is defined as the riskless rate plus a risk premium. Since there is rarely sufficient information about the future path of net operating income for these assets, often the current net operating income is used as a sufficient statistic for the future net income given an assumption about the market growth rate for this income stream. Assuming a flat 
term structure, the valuation formula for a commercial real estate asset can be written as,

$$
P_{0}=\sum_{t=1}^{\infty} \frac{R(1+g)^{t}}{\left(1+i_{t}\right)^{t}}=\frac{R}{(i-g)}
$$

where $g$ is the market growth rate for net operating income and $(i-g)$ is known in the real estate industry as the market capitalization rate, where it is assumed that $i-g>0$.

In a recent paper, Plazzi, Torous, and Valkanov (2010) find that metropolitan-level macroeconomic conditions appear to significantly impact the dynamics of the observed growth rates in net operating income across regional markets. In addition to these growth rate dynamics, macro-economic shocks to factor input prices, such as energy and labor costs, are also likely to affect the level of net operating income, and thus the level of asset prices, through total operating expenses. An important outstanding question is the degree to which shocks to the energy factor can be mitigated by building characteristics such as the energy efficiency of building engineering systems, such as heating, air conditioning and ventilation, or low energy-use lighting systems. To our knowledge, other than engineering simulation studies, there are no systematic empirical analyses of the relative operating efficiency of office buildings in U.S. metropolitan markets. The primary impediment to such studies is the lack of information on office building transaction prices along with information on buildinglevel total operating expenses, gross/net operating expenses, capitalization rates, location, energy-use metrics, and physical characteristics of the building.

In an influential recent paper? measure the economic value of the certification of "green buildings" that have either received an Energy Star rating or a LEED rating. They find that these buildings have asking rents (prices) that are about 3\% (16\%) higher per square foot than the asking rents (prices) found in otherwise spatially identical buildings. Two other recent studies by ? and ? also find higher asking rents, prices, and occupancy rates for buildings with green ratings. All three of these studies test for the effects of "green" ratings, using a hedonic representation of prices (asking rents) as a function of the characteristics and location of the building, including controls for whether each building was rated by LEED or Energy Star. Following the standard specification found in the hedonic pricing literature for real estate assets (see ?), the natural $\log$ of prices, $p,{ }^{5}$ is characterized by the set of all its physical attributes, found in the vector, $X_{i}$, including an indicator variable for the existence of a green rating, $x_{\text {green }}$, such that

$$
p_{i}=\beta_{0}+\beta_{i} X_{i}+\beta_{\text {green }} x_{\text {green }}+\epsilon_{i},
$$

\footnotetext{
${ }^{5}$ The semi-log specification is used to correct for the skew in the distribution of office building prices.
} 
where the $\beta$ s are coefficients to be estimated and $\epsilon_{i}$ is a building-specific residual. It is further assumed that the preferences of the commercial real estate investors are solely determined by the corresponding vector of attributes, including the ratings, that define the building. In contrast to Equation (2), the hedonic specification found in these studies does not control for the operating costs of the buildings nor does it control for the expected metropolitanlevel energy costs for the major fuels used by commercial office buildings; natural gas and electricity. Thus, the introduction of an indicator variable for "green" building ratings is likely to primarily account for the benefit stream associated with the ratings. The benefit stream would be expected to have a positive effect (i.e., positive $\beta_{\text {green }}$ ) although the effect on prices might be statistically insignificant. The causal determinants of this benefit, however, would be indeterminant. It could either be associated with real energy efficiency of the building, although this is unmeasured in this specification, or it could be due to the "plaquein-the-lobby-effect" or other labeling related attribute effects (see, for example, the label of an "architect designed building," as in ?).

A primary focus of this research is to assemble a data set suitable for the empirical estimation of Equation (2). Since Equation (2) measures current values as a function of

forward measures of fundamentals, our data requirements include forward measures for the metropolitan-level net-income growth rates, as identified by Plazzi et al. (2010), as well as building-level measures of the dynamics of key forward-looking factor input prices. Any empirical analysis of the highly heterogeneous stock of commercial office properties must also include numerous controls for the physical and utilization characteristics of these buildings, as is typically done in the estimation of hedonic price estimates. Another focus of our empirical work is to consider the affect of each building's contractual leasing structure on observed total operating expenses, Energy Star ratings, and asset values. Since the contractual structures of leases stipulate the way in which utility costs (primarily gas, electricity, water and taxes) are allocated to tenants and the degree of control tenants have on these costs, we develop measures for these leasing structures and consider several different empirical specifications for the factors that are associated with the adoption of one leasing structure versus another. Finally, we consider the relationship between the capital structure of commercial office buildings and their energy risk characteristics.

\section{The CoStar Data}

CoStar Group data used in our analysis comprises two separate components: the Properties data and the Comparable Transactions data. The Properties data includes information on subletting, direct, or relet space that is currently available for a large sample of office 
buildings in the United States. CoStar reports the "Weighted Average Rent," if there is rentable space available in the building; otherwise the Weighted Average Rent measure appears as missing. The Weighted Average Rent is measured as the weighted average "asking rent" for the available sublet, direct, or relet office space in each building at the time the data are downloaded (in our case, August/September 2010). The property data file also includes detailed information concerning the characteristics of the space that is available, including the location of the building, the dominant lease contract structure in the building, the amount of leaseable square footage available at the download date, an undated indicator variable for whether the building has been Energy Star rated at any time between 1999 and 2010, and the most recent sale transaction information (date of sale and sales price) if there have been recent transactions. There is also a large amount of brokerage contact information since these data are intended for use by leasing brokers and tenants seeking to dispose of, or obtain, office space.

There are a number of problems with the use of the CoStar measure of Weighted Average Rent in a statistical analysis of the correlation of building attributes, such as indicators for energy efficiency, and the market values of commercial office buildings. First, since there can be no assurance that the CoStar quoted "asking rent" is ever achieved in any future lease transaction, these rents cannot be viewed as directly equivalent to market prices. At best these asking rents might be viewed as a noisy measure of the landlord's evaluation of the market value of the available space given the available space characteristics. A second problem is that the CoStar measure of the Weighted Average Rent does not correspond to a homogeneous combination of available rental space. Since sublet, relet, and direct space would be expected to have very different quoted and realized rents per square foot, the Weighted Average Rent cannot be readily compared across buildings. For these rents to be comparable, additional information on the amount of each type of available space and the rents for each would be required. Unfortunately, the asking rent per square foot for each type of rental space is not reported in Costar. A final important limitation is sample-selection bias. Since the Weighted Average Rent appears as a missing value for all buildings that are fully leased, more poorly functioning buildings are likely to be systematically over-represented in the CoStar data.

Given these problems with using the CoStar Weighted Average Rent measure as a proxy for market value, we instead use the Costar Comparable Transaction data. As previously discussed, we limit our analysis to comparable arms-length and confirmed market transactions. ${ }^{6}$ These data again have no information on the actual rents paid by current lessors

\footnotetext{
${ }^{6}$ We eliminate all transactions for which there was a "non-arms-length" condition of sale due to such factors as a 1031 Exchange, a foreclosure, a sale between related entities, a title transfer, among other
} 
but they do have information on the actual confirmed transaction price and sale/recording dates for each office building. The data also include information on the overall building characteristics (building and lot square footage, typical floor area square footage, numbers of floors, etc), how many tenants, the location, and quality characteristics of the building, information on the first and second lien amounts, and the lien periodic payment amounts. For a subset of these data, there is also information on the annual net operating income at sale, the market-capitalization rate at sale, and the total annual expenses at sale.

Since the Comparables, or Transaction data, represent a subset of the Properties data, or asking-rent data, in CoStar, we merge the two data sets together by building name and address to obtain leasing characteristic information for the subset of office buildings that are in both data sets. The merged set of Transactions and Property data included 15,133 office buildings with complete records on all important covariates such as building square footage or the number of tenants. We also analyze a smaller data set that includes information on the leasing structure, annual net operating income at sale, the actual cap rate at sale, and the total annual expenses at sale.

\subsection{Energy Star Matching}

The CoStar sample of 15,133 buildings was then merged with a data set obtained from U.S. Environmental Protection Agency (EPA) that included all the buildings in the U.S. that have obtained an Energy Star rating. ${ }^{7}$ The Energy Star rating program was designed by the EPA and the U.S. Department of Energy to promote energy efficiency in the U.S. commercial real estate sector and thereby reduce greenhouse gas emissions. The program was started in 1999. The Energy Star rating is based on comparative national data, obtained from the Commercial Building Energy Consumption Survey, which set the annual benchmarks for energy usage levels across property types. A building's energy efficiency is measured as the residual between the actual and predicted energy usage of the building using actual utility bills. To receive an Energy Star label, a building must score in the top quartile of the EPA's energy performance rating system and must meet designated indoor air quality standards.

For each building, we obtained information on when the Energy Star rating was obtained

conditions. All of these sale conditions would affect prices due to the trading of tax basis in the case of 1031 exchanges or the auction structure in the case of foreclosure. Instead, we focus only on market transactions between unrelated persons.

${ }^{7}$ Many buildings in this sample were Energy Star rated multiple times and these ratings are often nonmonotonic in time (sometimes lower ratings are obtained at later dates). This non-monotonicity may arise because the Energy Star rating is relative to the population mean performance of office buildings. Thus, if an office building simply maintained its energy consumption profile, its ranking might fall if the overall population of U.S. buildings increases its energy efficiency. 
and the level of the rating the building received. ${ }^{8}$ The merged data sets led to 545 matches for Energy Star rated buildings. However, many of these matches were for Energy Star ratings that post-dated the actual observed transaction date. ${ }^{9}$ Using data on the actual date of each Energy Star grant, we matched 141 buildings that had an Energy Star rating by the time of sale.

\subsection{Local Weather Data Matching}

The weather data were obtained from Wolfram Schlenker at Columbia University. ${ }^{10}$ The weather station data are based on a rectangular grid system, called PRISM, that was developed at Oregon State University and covers the contiguous United States. ${ }^{11}$ The weather data include 471,159 grid points representing 2.5 mile squares with non-missing data. The data include the minimum and maximum temperature (Celsius) and the total precipitation (cm) for each day of a year for all of the 471,159 grids in the United States from 1950 through 2010. These data are interpolated from PRISMs monthly weather station averages to daily data and we aggregate them back into monthly data for our analysis. We associate the past twelve months of weather data for each building in the CoStar data with the weather data associated with the nearest grid point in the Schlenker, et al. data. Further details concerning the structure of the weather data are reported in the Appendix.

\subsection{Energy Auction Data Matching}

Incorporating information on the energy factor inputs for U.S. office building exposure requires a careful accounting for the institutional and contractual details of the regional and sub-regional gas and electricity markets in the U.S. We use data purchased from Platts (the data vendor) and compute a daily forward curve for power purchased on-peak and off-peak for all the trading hubs represented in our metropolitan areas. ${ }^{12}$ Platts gathers information on the power forward market from active brokers and traders and through the non-commercial departments (back offices) of companies. Since October 2007, this information has been augmented with auction prices from the Intercontinental Exchange (ICE) to form Platts forward market power daily assessment. Since more liquid locations and shorter term packages

\footnotetext{
${ }^{8}$ These rating vary between a minimum of 75 and a maximum of 100.

${ }^{9}$ Costar does not account for the date the Energy Star rating was received.

${ }^{10}$ http://www. columbia.edu/ ws2162/

${ }^{11}$ http://www.prism.oregonstate.edu/

${ }^{12}$ The location of these hubs is detailed in the Appendix. The subset of hubs that is described in the Appendix is currently being expanded and will be included in the next version of the paper. We currently use geographic interpolation to obtain estimates for the hubs for which we do not currently have the auction data. The additional five hubs will be included in the next version of the paper.
} 
trade more frequently on ICE, while less liquid locations and longer term packages trade more frequently over-the-counter (OTC), Platts is able to combine these sources to build a comprehensive picture of the forward market. Details of the methodology are described in the Appendix.

The raw data from Platts was formatted with single entries for each forward package. For a given trading date, a power hub, and a type of contract - on peak and off-peak there are single entries for the mark-to-market price for each forward package. This scheme characterizes the term-structure of power prices for a given trading date for contracts of varying maturities. Since the hub markets are defined geographically we then develop two measures for each building: 1) the 1-12 month daily average forward price per month (a measure of the short term contract forward price) that is measured contemporaneously, with a six-month lag and with a twelve-month lag; 2) the shape of the forward curve measured as the difference between the daily average for 1-12 month and 25-36 month contracts, standardized by the number of months in the curve, that is also measured contemporaneously, with a six-month lag and with a twelve-month lag. These measures were then matched to each building according to the electricity forward market hub that serves the building's location and were matched to the observed the month of the building's sale date. The electricity prices are quoted as $\$ / M W h$ (Mega Watts x hour) and Platts publishes these prices as of the delivery, or flow date, of the contract. Our use of delivery prices justifies our contemporaneous merges between electricity forward delivery price and the contemporaneous sale date of the building.

The resource costs (wholesale) price dynamics for natural gas are measured similarly to those of the electricity hubs. One important difference, is the natural gas market is benchmarked to a single auction at the Henry Hub. Following our strategy for the electricity prices and slopes, we measure the 1-12 month forward prices and the slopes for the Henry Hub. After the deregulation of the wholesale market for natural gas in the mid 1990's, the New York Mercantile Exchange (NYMEX) launched trading for monthly futures contracts with similar characteristics to those of crude oil. The standard NYMEX natural gas futures contract specifies physical delivery of 10,000 MMBtu (millions of British thermal unit) ratably delivered into Henry Hub - Louisiana. Until early 2000's NYMEX provided monthly contracts covering maturities of about 36 months out. After that the range of maturities was extended and it currently covers more then six years (72 months) out on a monthly basis. The NYMEX website provides more details on how the contracts are traded and the rules for settlement.

There is also an extensive network of natural gas pipelines connecting the production basins to large consumption areas (mainly large populated urban centers) and wholesale 
physical natural gas trading occurs in different hubs distributed in the continental U.S. These hubs are key points in the pipeline grid characterized by either being interconnections between major pipelines and/or access points to public utility gas companies. Of all those hubs, Henry Hub is the benchmark for price quotation. Henry Hub's importance comes from its location as an interconnecting point for multiple pipelines and because it is the most liquid hub for trading spot and futures contracts. Prices for other hubs (spot and OTC forwards) are typically quoted as a basis to Henry Hub. These basis quotes are, most of the time, a very small fraction of the full benchmark quote. We follow the market conventions and compute the near natural gas price as the Henry Hub monthly average of daily 1-12 month forward prices and measure the slope as the difference between the near price and the 60-72 month forward prices. We again compute these value contemporaneously, with a six-month lag and with a 12-month lag for each date. We then merge these time series data to the date of the observed sales transactions for each office building. Other specifics of our natural gas measurement is described in the Appendix.

\subsection{Summary Statistics for the CoStar Transaction Data}

As previously discussed, we focus on the forty- three metropolitan "office" market areas that account for the highest levels of employment in the category of Information, Finance, and Professional and Business Services, as measured by the Bureau of Labor Statistics in 2010. ${ }^{13}$ We represent the office market location of the building using market area designations developed by CoStar. In Table 2, we report the frequency of office building arms-length transactions that occurred from 2001 through 2010 for which we have complete price and characteristic information. As shown in the table, we have good transaction coverage for all of the large U.S. office markets identified by the Bureau of Labor Statistics. Our total sample size is 15,133 office properties.

Table 3 presents the distribution of transaction dates of sale for buildings that traded in our sample. The heavy trading volumes in the years 2005 through 2007 reflect the growth of the Commercial Mortgage Backed Securities market (an important source of mortgage lending for office transactions) during this period and the transaction boom fueled by the availability of cheap credit.

Table 4 presents the distribution of office buildings in the sample that had obtained at least one energy star rating by 2010. As shown, we were able to match to 547 Energy Star rated buildings in the U.S. EPA Energy Star ratings reports. When we further narrow the definition of the Energy Star rated buildings to buildings that were Energy Star rated at the

\footnotetext{
${ }^{13}$ Bureau of Labor Statistics, Employment Hours and Earnings, State and Metro Area, http://www.bls. gov/sae/data.htm.
} 


\section{Table 2: Market Location of CoStar Transaction Data}

This table presents the sample of office buildings that traded in arms-length transactions between 2001 and 2010 for which we have sales price, sales date, and information on the square footage of the building. The data were obtained from the COSTAR transactions data base.

\begin{tabular}{|c|c|c|c|c|}
\hline Costar Market Area & Number of Sales & Percentage of Total & Cumulative Frequency & Cumulative Percentage \\
\hline Atlanta & 915 & 6.05 & 915 & 6.05 \\
\hline Austin & 93 & 0.61 & 1008 & 6.66 \\
\hline Baltimore & 370 & 2.44 & 1378 & 9.11 \\
\hline Boston & 510 & 3.37 & 1888 & 12.48 \\
\hline Charlotte & 102 & 0.67 & 1990 & 13.15 \\
\hline Chicago & 909 & 6.01 & 2899 & 19.16 \\
\hline Cincinnati/Dayton & 156 & 1.03 & 3055 & 20.19 \\
\hline Cleveland & 154 & 1.02 & 3209 & 21.21 \\
\hline Dallas/Fort Worth & 306 & 2.02 & 3515 & 23.23 \\
\hline Denver & 617 & 4.08 & 4132 & 27.3 \\
\hline Detroit & 166 & 1.1 & 4298 & 28.4 \\
\hline East Bay/Oakland & 188 & 1.24 & 4486 & 29.64 \\
\hline Hartford & 48 & 0.32 & 4534 & 29.96 \\
\hline Houston & 218 & 1.44 & 4752 & 31.4 \\
\hline Indianapolis & 47 & 0.31 & 4799 & 31.71 \\
\hline Inland Empire (California) & 380 & 2.51 & 5179 & 34.22 \\
\hline Kansas City & 161 & 1.06 & 5340 & 35.29 \\
\hline Las Vegas & 528 & 3.49 & 5868 & 38.78 \\
\hline Long Island (New York) & 283 & 1.87 & 6151 & 40.65 \\
\hline Los Angeles & 799 & 5.28 & 6950 & 45.93 \\
\hline Marin/Sonoma & 33 & 0.22 & 6983 & 46.14 \\
\hline Milwaukee/Madison & 30 & 0.2 & 7013 & 46.34 \\
\hline Minneapolis/St Paul & 184 & 1.22 & 7197 & 47.56 \\
\hline Nashville & 52 & 0.34 & 7249 & 47.9 \\
\hline New York City & 243 & 1.61 & 7492 & 49.51 \\
\hline Northern New Jersey & 637 & 4.21 & 8129 & 53.72 \\
\hline Orange (California) & 464 & 3.07 & 8593 & 56.78 \\
\hline Orlando & 323 & 2.13 & 8916 & 58.92 \\
\hline Philadelphia & 762 & 5.04 & 9678 & 63.95 \\
\hline Phoenix & 1351 & 8.93 & 11029 & 72.88 \\
\hline Pittsburgh & 92 & 0.61 & 11121 & 73.49 \\
\hline Portland & 179 & 1.18 & 11300 & 74.67 \\
\hline Sacramento & 307 & 2.03 & 11607 & 76.7 \\
\hline San Antonio & 47 & 0.31 & 11654 & 77.01 \\
\hline San Diego & 292 & 1.93 & 11946 & 78.94 \\
\hline San Francisco & 185 & 1.22 & 12131 & 80.16 \\
\hline Seattle/Puget Sound & 410 & 2.71 & 12541 & 82.87 \\
\hline South Bay/San Jose & 161 & 1.06 & 12702 & 83.94 \\
\hline South Florida & 707 & 4.67 & 13409 & 88.61 \\
\hline St. Louis & 119 & 0.79 & 13528 & 89.39 \\
\hline Tampa/St Petersburg & 527 & 3.48 & 14055 & 92.88 \\
\hline Washington DC & 1022 & 6.75 & 15077 & 99.63 \\
\hline Westchester/So Connecticut & 56 & 0.37 & 15133 & 100 \\
\hline
\end{tabular}


Table 3: Transaction Dates for the Arms-Length Office Building COSTAR Transactions This table presents the frequency of trades for the office buildings in our sample. Our sample of buildings are office properties that traded in arms-length transactions between 2001 and 2010 for which we have sales price, sales date, and information on the square footage of the building. The data were obtained from the CoStar transactions data base.

\begin{tabular}{lrrrr}
\hline Sale Year & Number of Sales & Percentage of Total & Cumulative Frequency & Cumulative Percentage \\
\hline 2001 & 10 & 0.07 & 10 & 0.07 \\
2002 & 227 & 1.5 & 237 & 1.57 \\
2003 & 1806 & 11.93 & 2043 & 13.5 \\
2004 & 2457 & 16.24 & 4500 & 29.74 \\
2005 & 2534 & 16.74 & 7034 & 46.48 \\
2006 & 2570 & 16.98 & 9604 & 63.46 \\
2007 & 2641 & 17.45 & 12245 & 80.92 \\
2008 & 1757 & 11.61 & 14002 & 92.53 \\
2009 & 935 & 6.18 & 14937 & 98.7 \\
2010 & 196 & 1.3 & 15133 & 100 \\
\hline
\end{tabular}

time of their sale, we have only 141 Energy Star Ratings at the time of sale. This feature of the data arises because the incidence of Energy Star rated buildings has been growing. However, most buildings rated by Energy Star received their ratings at the end of the sample in 2008, 2009 and 2010, and typically these rating dates are several years after the properties actually sold.

In the Appendix, we map the location of the Energy Star rated buildings in the Los Angeles and San Franciso markets. The maps highlight the important geographic structure of the Energy Star rated building locations. For the most part, the Energy Star rated office buildings are located in more central locations, the Central Business District or the Sub-Regional Business District, within the CoStar Markets. A further geographic detail, which is not obvious from Table 4, is that the preponderance of these Energy Star certified buildings are located in the states of California, Florida, Texas, New York/New Jersey, and Washington DC/Maryland. Several markets have only one or two Energy Star rated buildings.

Table 5 provides the summary statistics for other important characteristics of the office building transaction data. In the top panel of the table, we report summary statistics for the 1-12 month power and natural gas forward prices that were observed at the time the building traded. We also report the values for the slope of the forward curve for power and natural gas on the sale date. As reported, the average electricity forward price (in $\$ / \mathrm{MWh}$ ), that is observed at the sale date for the traded office buildings is $\$ 68.65 / \mathrm{MWh}$, the standard deviation is $\$ 19.23 / \mathrm{MWh}$, and there is considerable variability, with a high of 
Table 4: Energy Star Ratings Frequencies between 2001 and 2010

The upper panel of the table presents the numbers of office buildings that even received at least one Energy Star rating between 2001 and 2010. The lower panel of the table reports the number of office buildings in the sample that had an Energy Star rating by the time of their sale.

\begin{tabular}{lrrrr}
\hline Energy Star & $\begin{array}{r}\text { Number } \\
\text { of Sales }\end{array}$ & $\begin{array}{r}\text { Percentage } \\
\text { of Total }\end{array}$ & $\begin{array}{r}\text { Cumulative } \\
\text { Frequency }\end{array}$ & $\begin{array}{r}\text { Cumulative } \\
\text { Percentage }\end{array}$ \\
\hline Never EnergyStar Rated in period & 14586 & 96.39 & 14586 & 96.39 \\
EnergyStar Rated in period & 547 & 3.61 & 15133 & 100 \\
\hline Never EnergyStar Rated by time of Sale & 14992 & 99.07 & 14992 & 99.07 \\
EnergyStar Rated by time of Sale & 141 & 0.93 & 15133 & 100 \\
\hline Total Energystar Annual Ratings $(1999-2010)$ & 1222 & & & \\
\hline
\end{tabular}

$\$ 161.71 / \mathrm{MWh}$ and a low of $\$ 30.78 / \mathrm{MWh}$. Although not shown, there is also considerable variability in these prices across hub regions, so office buildings in different hubs at the same time period experienced different prices. The average slope of the power forward curve is slightly downward sloping per month \$-0.819. However, here again there is considerable time-series and hub variation, with observations with very steep forward curves indicating expectations that power prices/MWh were expected to rise, $\$ 13.67 / \mathrm{MWh} / \mathrm{month}$, and very steeply downward sloping forward price curves, \$-21.74/MWh/month.

As previously discussed, the natural gas forward prices only vary in the time series since we measure all buildings at the Henry Hub benchmark forward price following industry convention. As shown in Table 5 , the average forward price (in $\$ / \mathrm{MMBtu}$ ) is $\$ 7.38$ with a standard deviation of $\$ 2.047$. The maximum price was less that twice the average price. The observed slope of the forward curve at the transaction date was slightly negative at $\$-0.18$ MMBtu/month and, similar to the power markets, the minimum and maximum values vary between positively and negatively sloped forward price curves.

The third panel of Table 5 provides the summary statistics for the twelve months prior to the sale date of the property. We report the average standard deviation of weather data for the minimum temperature, maximum temperature, and the precipitation over the prior twelve months for each building. As shown, the average standard deviation for the maximum temperatures was 69.14 degrees Farenheit and was 58.49 degrees Farenheit for the minimum temperatures. The precipitation standard deviations are significantly smaller at .045 .

In the third panel of Table 5, we report the summary statistics for the trading price and the building characteristics of the arms-length transactions. The average observed price per square foot was $\$ 183.89$, with a standard deviation of $\$ 108.72$ per square foot, and the average building size was $54,747.95$ square feet with a standard deviation of $122,254.48$ 


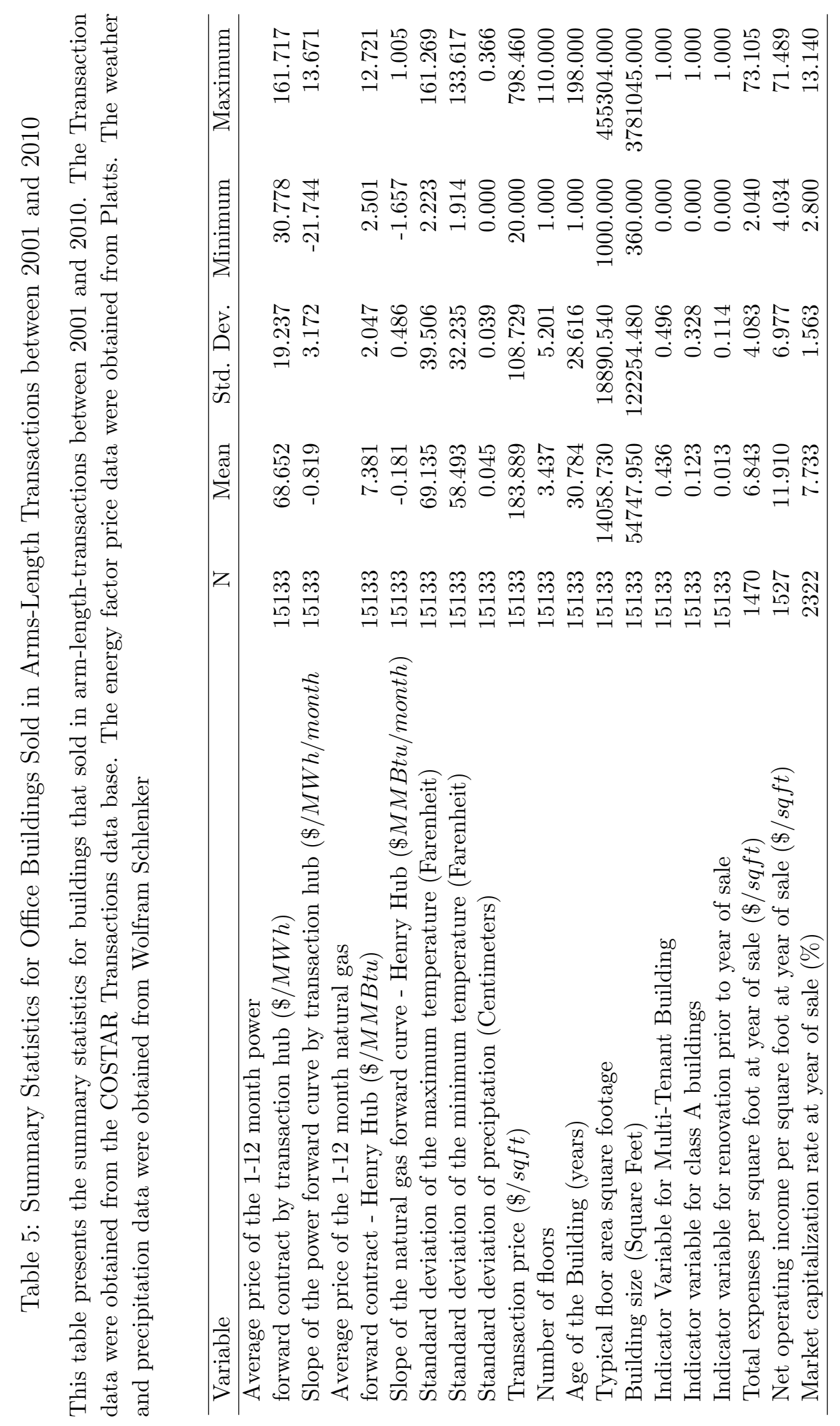


square feet. The average number of floors was 3.44 and the largest building had 110 floors. The typical rented square footage per tenant was 14,058.73 square feet in these buildings and the standard deviation was 18,890.54. Forty four percent of the buildings in the transaction data are multi-tenant buildings and twelve percent of the buildings are class A buildings. Only one $1.3 \%$ of the buildings in the sample were renovated prior to the sale.

For a subset of the transaction data, we have information on the net operating income, the total operating expenses, and the observed capitalization rate at the time of the sale. ${ }^{14}$ As reported in the bottom panel of Table 5, for the sub-sample of sales, the average net operating income per square foot at the time of sale was $\$ 11.91$ and the standard deviation was $\$ 6.98$. The total expenses per square foot at the time of sale was $\$ 6.84$ and the standard deviation was $\$ 4.08$. Finally, the observed capitalization rate at the time of sale was $7.73 \%$ with a minimum value of $2.8 \%$ and $13.14 \%$ over the period 2001 to 2010 .

\section{The Investor's Energy Star Rating Decision}

We first consider the exogenous factors that may lead a building owner to apply for and successfully achieve an Energy Star rating for a commercial office building. As previously discussed, applying for an Energy Star rating involves significant costs in the form of the time and effort required for engineers to verify utility bills and certify the level of air quality in the building. There may also be costs associated with retrofitting the building, if the current operating performance is below the top quartile of performance. Following the logic of standard investment rules, we would expect the investor to undertake the Energy Star application process and, if need be, retrofit the building to successfully achieve an Energy Star rating, if the present value of the benefits from that investment exceeded its costs. ${ }^{15}$ As is clear from the previous discussion of the asset price equation, Equation (2), the increment to the asset price could arise from the increase in gross income, a decrease in vacancy rates, a decrease in total operating costs, an increase in the net operating income growth rate, or a decrease in the risk of the asset due to reductions in the volatility of the buildings cash flows. Whatever the source of the benefits from the rating, however, the increment to the asset's value after the successful Energy Star rating must exceed the cost of obtaining the rating given the investor's opportunity costs.

An additional dilemma for the econometrician is that the underlying fundamental fac-

\footnotetext{
${ }^{14}$ The capitalization rate is the discount rate that translates the observed net operating income into the observed transaction price at the time of sale, assuming an infinite investment horizon, $\sum_{t=1}^{\infty} \frac{N O I}{\text { capitalization rate }}=$ Sales Price.

${ }^{15}$ Of course, real options considerations might also enter this calculus leading to the consideration of the second moments of fundamental factors. Grenadier (2005)
} 
tors defined in Equation (2) are unobserved. Instead, the econometrician observes only an outcome variable that is one if the decision to obtain an Energy Star rating meets the investment threshold for the investor. Future observations on the price of the asset are, of course, conditioned on the prior decision to obtain, or not to obtain, the Energy Star rating and this decisions could affect observed levels and dynamics of asset prices in important ways. A further problem, is that the Energy Star decision is often a dynamic contracting problem that is solved contemporaneously with leasing and debt contracting decisions. This further complication implies that the Energy Star decision may be co-determined with these other contracting decisions.

In its simplest form, the utility an investor derives from obtaining an Energy Star rating in a given period can be associated with a linear function of building characteristics and other exogenous market variables, $v_{i t}$, affecting costs and building value,

$$
U_{i t}=\gamma v_{i t}+\mu_{i t}
$$

where $\mu_{i t}$ is a residual. Utility is a latent variable that is not observed, however, we do observe the choice made by the investor at each period. Obtaining an Energy Star rating thus corresponds to a response variable, $y_{i t}$, with a value to one. If the Energy Star rating is achieved, this implies that the latent utility is positive,

$$
y_{i t}=1 \Rightarrow U_{i t}>0
$$

Under the assumption that the residual follows an i.i.d extreme value distribution, the probability of become Energy Star rating is given by the logistic function.

$$
\operatorname{Pr}\left(y_{i t}=1\right)=\operatorname{Pr}\left(\gamma v_{i t}+\mu_{i t}>0\right)=\operatorname{Pr}\left(\mu_{i t}>-\gamma v_{i t}\right)=\frac{1}{\left(1+\exp \left(\gamma v_{i t}\right)\right.}
$$

The coefficients of this choice behavior can be estimated using maximum likelihood. The likelihood function is calculated by aggregating the probability of the observed choice stream for each building.

$$
\log L(\theta ; v)=\Sigma_{n=1}^{N} \ln \left[\operatorname{Pr}\left(y_{i t}: y_{n t}=1 \quad \forall t=1, \ldots, T_{n}\right)\right]
$$

We report the results of the maximum likelihood estimation for the Energy Star choice in Table 6. Since we only observe the year of the Energy Star rating, we compute the annualized average near contract prices and the annualized value of the slope for power and gas for each building. We also have measures for the quality of the building, the age and the 
square footage at the Energy Star grant date and the quality level of the building. Many of the Energy Star rated buildings in the sample are rated multiple times over the period 1999 through 2010. For every building in the sample, we construct a panel of annual observations on market and building characteristics including an indicator variable for whether the building became Energy Star rated in that year. Our estimator accounts for the path dependence of these decisions since a sub-sample of the buildings were Energy Star rated every year, some buildings were Energy Star rated more than once but not every year, some were Energy Star rated only once in the sample period, and some buildings were never Energy Star rated over the period. Since the Costar data only gives us a cross-sectional snapshot of the building at the transaction data we only use building characteristics that are measurable over time, such as age, building square footage, and quality level. We merge the building level characteristics with time varying market characteristics for the energy forward prices and the weather variables and these are measured year-by-year from the building's transaction date. ${ }^{16}$

As shown in Table 6, the decision to Energy Star rate a building appears to be importantly related to the energy factor prices in markets. There is a statistically and economically negative relationship between the six month lagged price level of the one to twelve month electricity contract and a statistically positive relationship with the slope of the electricity forward curve indicating expectations are for electricity prices to rise. The interpretation of these results is that a one unit change in the average level of local hub electricity prices would be expected to lead to a $-1.8 \%$ decrease in the log odds ratio that the Energy Star rating is achieved, whereas a similar magnitude change in the expectation that the hub price for electricity delivered in five years would lead to a $3.47 \%$ increase in the odds that an Energy Star rating would be achieved, holding other effects constant. Changes in the level of Henry Hub natural gas prices do not have a statistically significant effect on the likelihood that an Energy Star rating is achieved, whereas expectations that natural gas prices are expected to rise have a statistically negative effect on the probability of achieving an Energy Star rating. MSAs with higher variance in minimum temperature are shown to be statistically positively related to the decision to obtain an Energy Star rating in a given year, whereas increased variance in maximum temperatures is negatively associated with obtaining an Energy Star rating. These results suggest that it is the variance in heating that is the primary driver of Energy Star rating decisions. As expected, the results show that Class A buildings are more likely to obtain an Energy Star rating as are larger buildings and newer buildings.

Of course, an important caveat with our Logit results is that we have no additional controls for whether the buildings in the CoStar sample are actually energy efficient, whether

\footnotetext{
${ }^{16}$ We were only able to obtain local weather data for each building through 2005 . We use the 2005 weather metrics for Energy Star rating events after 2005.
} 


\section{Table 6: Logit Estimation of the Energy Star Rating Choice}

This table presents maximum likelihood estimates for the probability that a building sucessfully received an Energy Star rating in a given year as a function of local energy-market and weather characteristics and building and market characteristics. The annual Energy Star rating indicator for each building was obtained from the U.S. Environmental Protection Agency, the office building data was obtained from CoStar, the electricity forward curve data was estimated using data from Platts, the natural gas data was obtained from NYMEX, and the weather data was obtained from Wolfram Schlenker. The first two columns report the results for estimating the time path of Energy Star ratings for building between 1999 and 2010 (true for 1222 annual Energy Star building ratings). The reported test statistics are distributed Chi Squared.

\begin{tabular}{|c|c|c|}
\hline Variable & $\begin{array}{l}\text { Parameter } \\
\text { Estimate }\end{array}$ & $\begin{array}{r}\text { Standard } \\
\text { Error }\end{array}$ \\
\hline Intercept & $-5.949^{* * *}$ & 0.317 \\
\hline Annual Average of the six month lag price of the 1-12 month power & & \\
\hline forward contract at sale by transaction hub & $-0.018^{* * *}$ & 0.004 \\
\hline Annual Average of the six month lag slope of the power forward curve & $0.0347^{* *}$ & 0.016 \\
\hline Annual average of the six month lag price of the 1-12 month & & \\
\hline natural gas forward contract at sale & -0.035 & 0.026 \\
\hline Annual average of the six month lag slope of the natural gas forward curve & $-0.055^{* * *}$ & 0.0125 \\
\hline Standard Deviation of 12 Month Maximum Temperature & $-0.014^{* * *}$ & 0.005 \\
\hline Standard Deviation of 12 Month Minimum Temperature & $0.018^{* * *}$ & 0.006 \\
\hline Standard Deviation of 12 Month Precipitation & -0.158 & 1.133 \\
\hline Age of the Building & $-0.015^{* * *}$ & 0.002 \\
\hline Building square footage & $0.020^{* * *}$ & 0.001 \\
\hline Indicator variable for class A buildings & $2.847^{* * *}$ & 0.081 \\
\hline Market Fixed Effects & Yes & \\
\hline Year Fixed Effects & Yes & \\
\hline Likelihood Ratio Test & $4184.83^{* * *}$ & \\
\hline Number of Observations (Balanced panel building per year) & 173,640 & \\
\hline
\end{tabular}


or not they have an Energy Star rating. Thus, our specification only represents decisions whereby the labeling decision was an NPV positive decision, not whether overall objective energy efficiency measures lead buildings, on average, to obtain an Energy Star rating. In the next sections of the paper, we will further explore the operating expense and net operating income characteristics of buildings to better understand the relationship between the Energy Star label and relative building operating performance.

\section{Empirical Results with Transactions Prices}

As previously, discussed due to data limitation all previous studies of the effects of energy metrics or environmental and architectural factors on commercial office building values have applied hedonic approaches similar to that of Equation (3) (for examples, see Wheaton and Torto, 1994; ?; ?; ?; ?; ?, among others). These studies usually find that the benefits of energy certification or the environmental/architectural attributes of buildings are positive factors leading to a premium on buildings with these attributes. These results, however, say nothing about whether the investment in the certificate or the environmental or architectural attributes are Net Present Value positive or whether, in the case of energy certification the buildings are in effect energy saving. To answer the question whether energy certification, based on quantifiable energy related metrics like the Energy Star ratings, requires a specification that is closer to Equation (2) and controls for costs and expected energy-related factor input prices.

In Table 7, we report the results of two specifications: in the first four columns we report the results for the hedonic specification; in the fifth and sixth columns we report the results for the forward looking asset pricing specification defined by Equation (2). As shown in the Table, the hedonic specification indicates that higher building values are associated with higher near-term power forward prices and a more steeply sloped forward curve even after controlling for market fixed effects. Thus, the level of net operating income or its growth rate appears to more than compensate for exposure to increase electricity costs, which is the primary energy exposure for commercial office buildings. Higher prices for natural gas nearterm futures contracts have a statistically significant and negative association with building prices per square foot indicating that the cost effect of this factor input is not compensated by rents. The effects of the standard deviation in the twelve-month maximum temperature has a statistically significant negative effect of price and the and the standard deviation of minimum weather temperature has a smaller positive effect on the price per square foot. As shown, class A buildings and those buildings that were Energy Star rated prior to the sale have economically and statistically significant positive associations with building values. The 


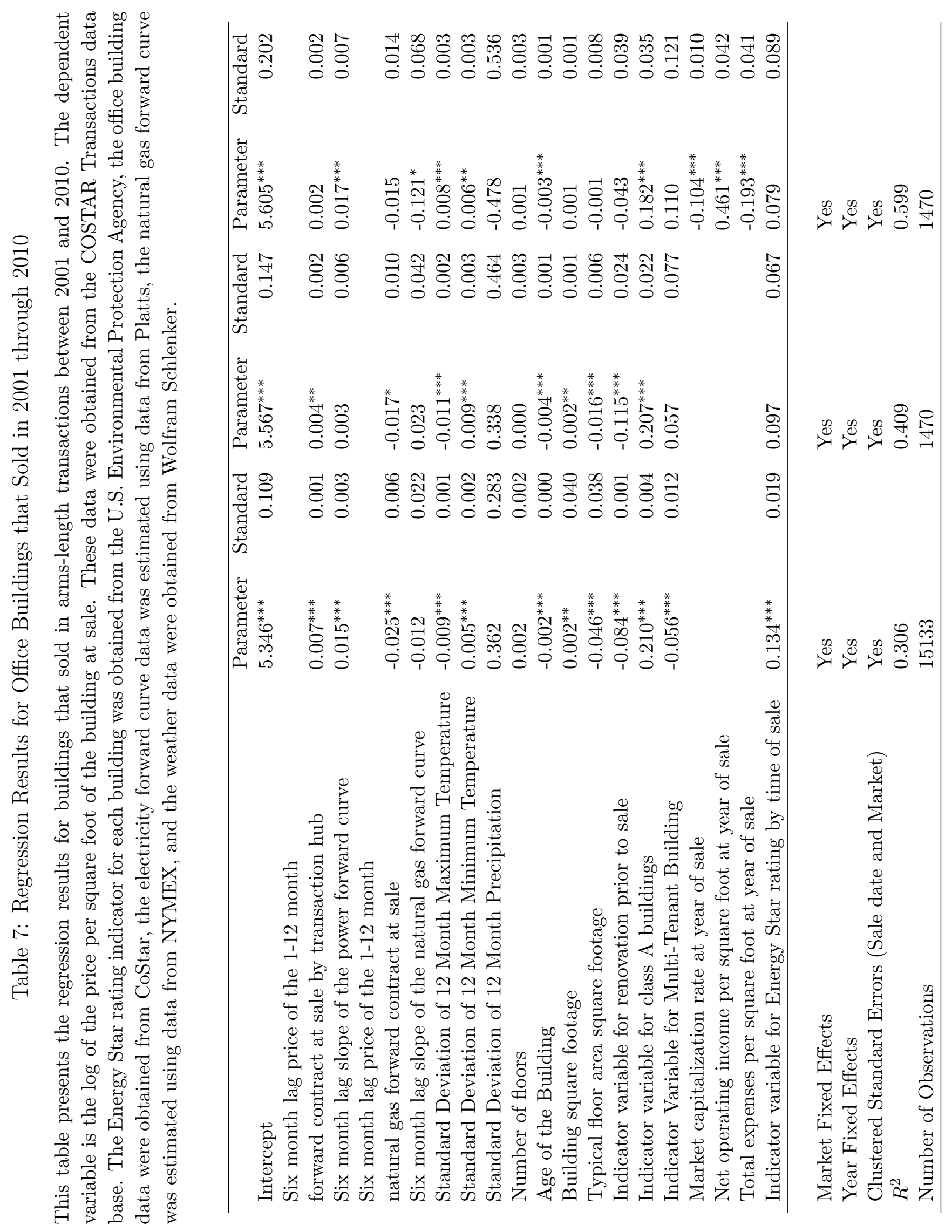


Energy Star result is similar to results from hedonic specifications in prior papers. Building attributes that negatively affect building values include age, multi-tenant buildings, and large rentable floor plates.

In the third and fourth columns of Table 7 , we re-estimate the hedonic regression for a sub-sample of buildings for which we have data required to estimate the forward looking asset pricing specification defined by Equation (2). As shown, the results are nearly identical to those for the larger sample although statistical significance is lessened due to the smaller sample size. The smaller sample reduces statistical power and now the Energy Star rating, which is based on quantitative measures of energy efficiency of commercial office buildings, does not have a statistically significant positive association with the transaction prices of these buildings. Without further controls, it is not possible to conclude that these effects are due to the relative efficiency of these buildings or to the "plaque-on-the-wall" effect of the certification.

In the fifth and sixth columns of Table 7 , we report the results where we control for the total expenses, market capitalization rate capturing the expected growth rate in rents, and the net operating income for the building at the time of sale. In this specification we find that the slope of the electricity forward curve is positively associated with log of building price per square foot and the slope of the natural gas forward curve is positively associated with log prices suggesting that auction market bets that energy prices will rise are associated with higher expenses per square foot. The standard deviation of minimum and maximum temperatures also has a statistically significant and positive effect on the log of prices. These results appear to suggest that the primary driver of higher weather related costs are associated with air conditioning costs in the summer rather than heating costs in the winter months. Total expenses, the capitalization rate, and net operating income are all economically and statistically significant with the anticipated signs. Buildings with higher total expenses and that were exposed to higher market capitalization rates had lower transaction prices whereas everything else equal, buildings with higher net incomes have higher prices. The revealing result is that controlling for operating expenses, factor prices, and interest rates eliminates the statistically significant and positive Energy Star channel to transaction prices. This result suggests that the Energy Star rating appears to have a lesser effect on transaction prices that is not statistically significantly different from zero once appropriate controls for expenses, rents, and interests are introduced. Of course, our measure of operating expenses includes property taxes, labor costs, and utilities (primarily electricity, gas, and water), so it might be highly correlated with the Energy Star metric since utilities are on average about $20 \%$ to $30 \%$ of total operating expenses nationally. ${ }^{17}$

\footnotetext{
${ }^{17}$ Computed by the authors using various BOMA publications.
} 
To better understand the relationship between the Energy Star rating and total operating expenses, net operating income, and the capitalization rates at sale of the office buildings, we report three separate regressions: i) net operating income per square foot; ii) operating expenses per square foot; and iii) the capitalization rate. The results of these regressions are reported in Table 8. Overall as shown, the Energy Star rating of the building does not have a statistically significant effect on operating expenses, net operating income, or the capitalization rate of transacted buildings. In contrast, the higher values of the six month lag in the one to twelve month electricity forward prices have a statistically significant positive association with net operating expenses, the slope of the electricity forward curve is associated with higher total operating expenses, and the level of the Henry Hub natural gas forward prices is positively associated with higher operating expenses, as expected. The variance in the minimum weather temperature conditions over the twelve months prior to the sale also has a statistically significant positive effect on operating expenses. More variance in the maximum temperature appears to be associated with lower net operating income and higher market capitalization rates, and does not have a statistically significant affect on operating expenses. There appear to be scale economies associated with larger buildings and larger rentable floor plates, however, class A buildings and multi-tenant buildings have economically and statistically significantly higher total operating expenses.

Given the results in Table 8, the net operating income and operating expenses appear themselves be functions of the local supply and demand factors, suggesting that controls should be introduced for the joint-endogeneity of net operating income and operating expenses in a building prices specification for Equation (2). Since the market capitalization rate, is in large part a function of the interest rate, we assume that it is exogenous. In Table 9, we report the results for a three stage least squares estimation of endogenous net operating income and operating expenses as a function of exogenous factors such as the local energy factor input prices for natural gas and electricity, the local weather conditions, building characteristics, local market fixed effects, and year fixed effects and the Equation (2) specification with the instrumented value of net operating income, the instrumented value of operating expenses, and the market determined capitalization rate. Again, the three stage least squares estimation is using the sub-sample of transactions for which we have information on operating expenses, net operating income, and the market capitalization rate at sale. As shown in Table 9, operating expenses per square foot have a statistically significant and positive association with the slope of the natural gas forward curves, implying that the higher the future bets from the auction markets on the cost of this factor input the higher the expected operating costs of the building. The energy factor inputs appear to have no statistically significant effect on operating income. More variance in the max- 


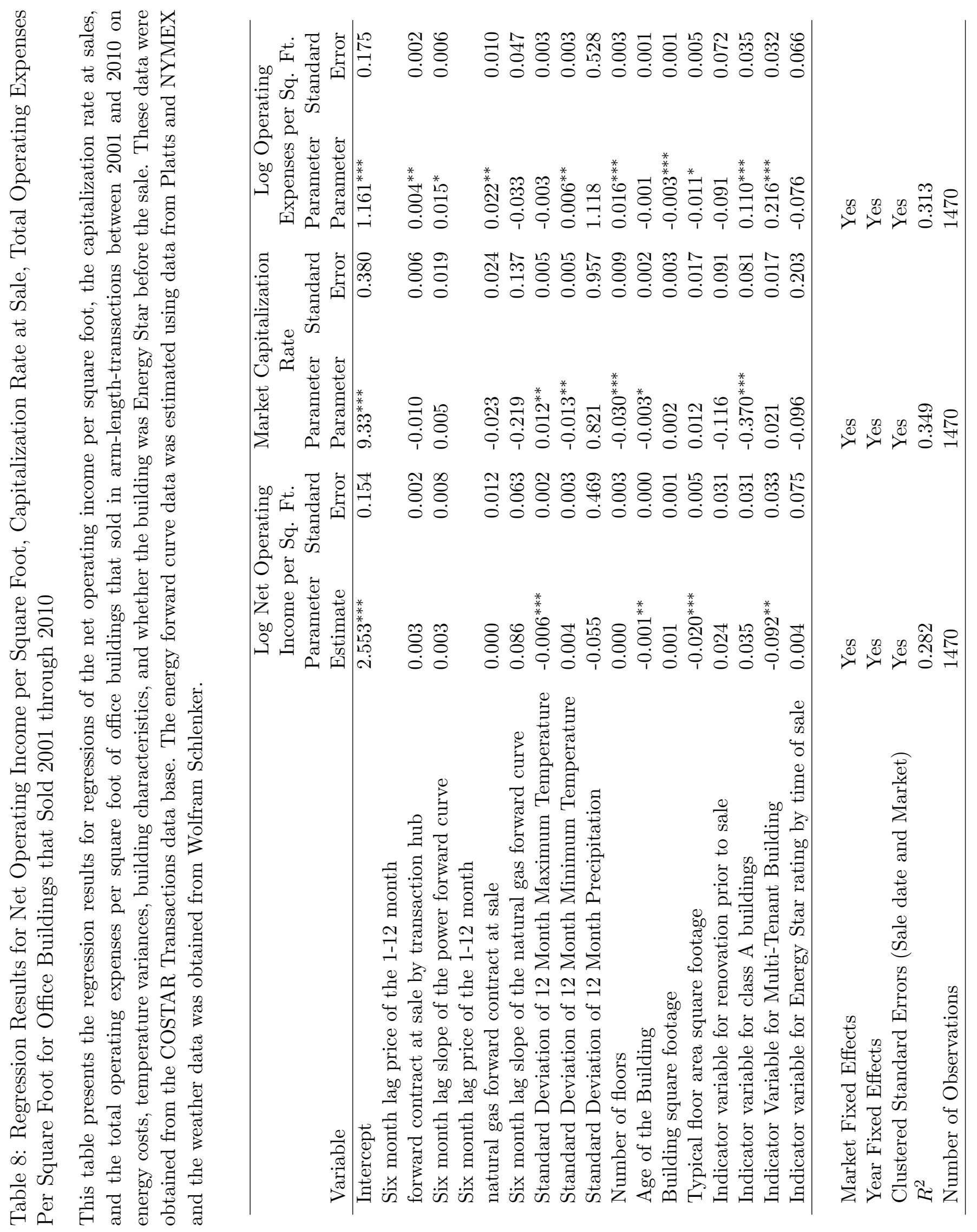


imum temperature in the local markets has a statistically significant negative association with operating income per square foot and more variance in precipitation has a statistically significant positive effect on operating costs after controlling for local market fixed effects. More floors and multi-tenant buildings are associated with statistically significantly higher operating expenses and larger floor plates rented by tenants are associated with lower net operating income probably due to the discounts afforded to larger block rentals.

Instrumenting for operating expenses and net operating income in the price equation leads to results that are very similar to those reported in Table 7 that does not use a Three Stage Least Squared Estimator. As expected from Equation (2), the capitalization rate, the net operating income and the operating expenses are the key determinants of the transaction values of building. We also introduce two indicator values for Energy Star ratings from the earlier period of 2003 through 2005 and Energy Star ratings from the latest period, 2006 through 2009, when it is thought to be more difficult to get into the top twenty fifth percentile of energy efficiency due to the increased competition for these scores among building owners. As shown in Table 9 last two rows of the last column of the table, once appropriate controls for net operating income, operating expenses, and capitalization rates are introduced into the

pricing equation, there appears to be no statistically significant additional effect of obtaining an Energy Star label even in the most recent period.

These results suggest that the Energy Star rating can only be viewed as having a muted effect on building transactions prices at least through the expense channel. Accounting for the primary determinants of office building asset prices net rents, expenses, energy factor prices and interest rates appears to leave no further room for either the "plaque-on-the-wall" effect or the incremental savings associated with Energy Star certification. There is, of course, one further control that is missing from these specifications and that is the cost associated with actually obtaining an Energy Star rating. Given our result that the benefits of the Energy Star certification appear to proxy for important missing factors in office building asset prices, it unlikely that inclusion of these costs could change our conclusions that the measurable net benefit of Energy Star is not statistically associated with transactions values per square foot.

\section{Leases}

Important reductions in the energy consumption of U.S. buildings are technologically feasible, but building owners-landlords-often do not receive the proper economic incentives to carry out the required investments. The incentive failures occur in two related markets: the rental market where lease contracts often inhibit energy efficiency, and the mortgage market 


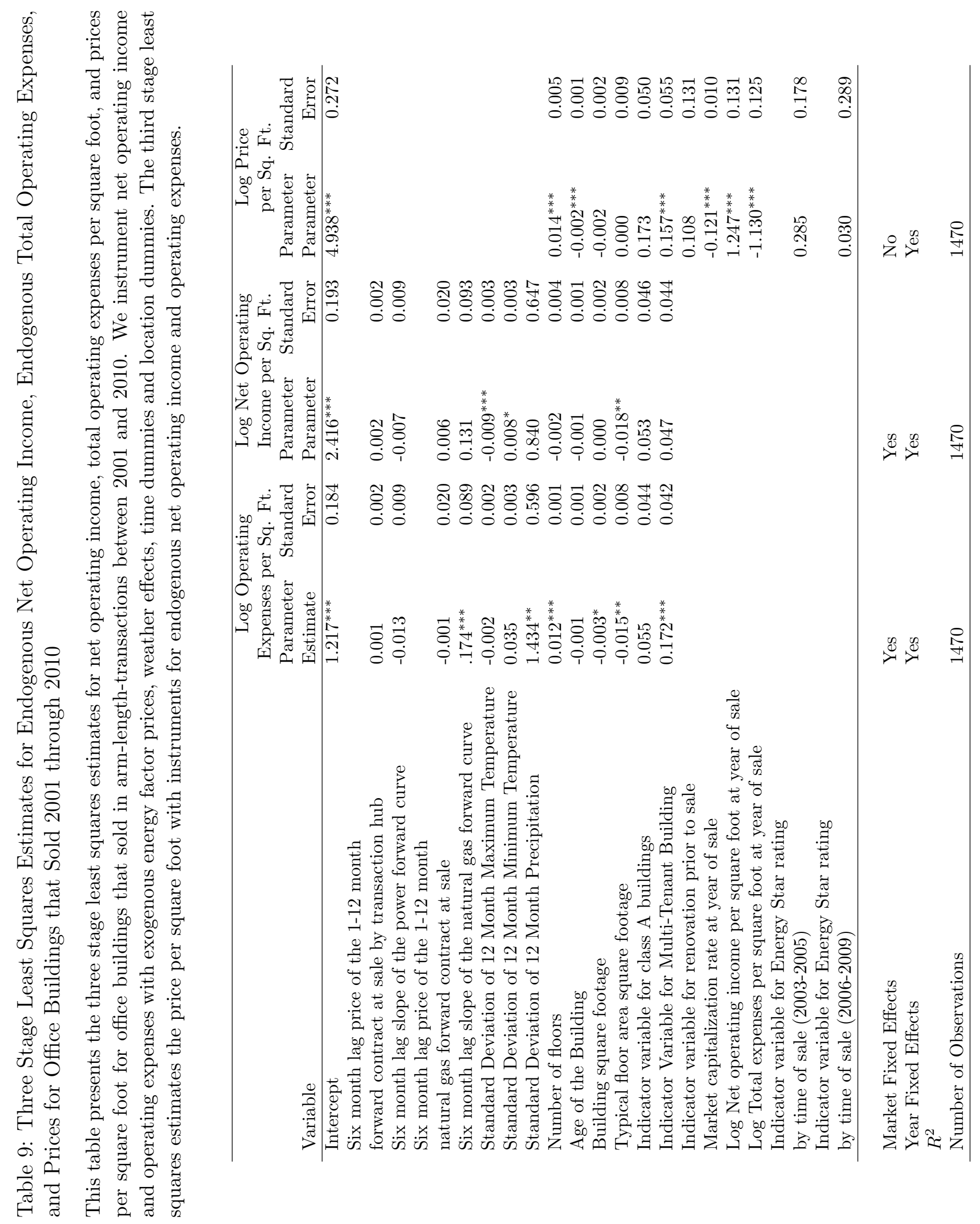


where loan underwriting procedures also inhibit energy efficient investments. Lease contracts contain many common basic terms and conditions that set the terms for payments and services received between the tenant and landlord in three dimensions:

1. Space rent. The core purpose of a lease is to identify the space provided to the tenant and the rent paid to the landlord. The lease will also typically identify the physical condition of the space and any improvements the landlord will provide.

2. Building operating expenses. Building operating costs include energy use, property taxes, building operations and maintenance, and insurance. Lease contracts will identify how the payments for these expenses are to be allocated between the landlord and the tenants. Lease contracts will also typically indicate the quality level promised by the landlord for building operations and maintenance.

3. Building capital expenditures. Building capital expenditures cover a variety of investments that maintain or improve the building, including investments to improve the building's energy efficiency. Lease contracts will identify how the amortized costs of these investments are to be shared between the landlord and the tenants.

Lease contracts must also indicate the period over which the contract pertains. On longerterm contracts, the lease will indicate how payments in the three categories will change over time, quite possibly including how rising operating costs will be shared between the landlord and the tenants. Furthermore, lease contracts may allow a variety of options such as allowing either the landlord or tenant to break the lease under specified conditions.

Lease contracts for commercial buildings commonly take one of three main formats: full service leases, net leases, and modified gross leases. Full service leases require that the tenant makes a single payment that covers the tenant's responsibility for space rent and operating expenses. The individual components are typically not identified. This allows the landlord freedom to reduce operating expenses, including energy costs, by making efficient capital expenditures (subject to the minimum standard for building services and maintenance specified in the lease contract).

With net leases, the tenant agrees to pay for both space rent and the tenant's actual or allocated share of the specified operating expenses. The operating expenses may include energy, property taxes, and insurance-a lease that includes all three expense categories is call a "triple net" lease, but other combinations are possible. We focus here on the set of Net leases that at least include electricity, which then requires that the tenant's space have direct metering.

Modified gross lease contracts specify a specific payment for the space rent plus and stipulate an actual amount to be paid for operating expenses in the first year. For later 
years, the landlord provides an audit of building expenses, and the tenants pays a prorated share of the realized percentage increase in the building expenses. Modified gross leases and Net leases share the feature that the tenant pays a share of the building's operating expenses, but on modified gross leases the tenant pays a prorated share of the building's total expenses, which are thus are independent of the tenant's actual energy usage. For this reason, modified gross leases are commonly used in buildings where energy metering of each tenant's space is not available.

\subsection{Lease Contracts and Energy Efficient: Economic Theory}

We begin with an outline of the economic theory of how lease contracts can affect energy efficiency in office buildings. The assumed environment is that of a multi-tenant office building. Lease contracts affect energy efficiency through two distinct channels: (1) tenant and landlord energy use, taking as given the building's current energy efficiency, and (2) landlord investments that would improve the building's energy efficiency. We focus first on the energy use, taking as given the building's current energy efficiency.

\subsubsection{Contract Theory, Uncertainty, and Energy Use}

Contract theory is the part of economics that studies the incentives received by contract participants to take various actions. The specific implications depend critically on the environment in which the contracting process is assumed to occur. Uncertainty regarding a building's energy usage, including the possibility of asymmetric information between the landlord and the tenants, is critical to understand the impact of lease contracts on energy efficiency. In particular, if there were complete knowledge concerning the dollar costs of energy usage, then lease contracts would have no impact on energy efficiency. This can be illustrated by a simple example in which the space rent is $\$ 1,000$ and the only relevant building expense is the tenant's energy use of $\$ 100$. It is thus apparent that the tenant will pay a total amount of $\$ 1,100$. Under a Full Service or Modified Gross lease, the total amount of $\$ 1,100$ would be paid by the tenant to directly to the landlord. Under a Net Lease, the tenant pays $\$ 1,000$ to the landlord and $\$ 100$ to the utility company, for the same total payment of $\$ 1,00$. It is thus apparent that the economic outcome is identical under the three contracts.

The situation changes significantly once there is uncertainty concerning the likely energy costs. For example, suppose there is a 50 percent chance the energy costs will be $\$ 50$ and a 50 percent chance the energy costs will be $\$ 150$, so the expected energy cost remains $\$ 100$ as in the example. Under the Full Service contract, the landlord bears the risk that the 
actual energy cost will be $\$ 150$ and benefits if the actual cost is $\$ 50$. Under a Net contract, in contrast, the additional energy costs or benefits are realized by the tenant. The outcome under a Modified Gross lease is potentially more complex, but assuming all tenants have the same energy cost outcome, any additional energy costs or benefits will also be realized by the tenant.

The implication is that lease contracts have an insurance component, with the risk of high energy cost outcomes borne by the landlord under a Full Service lease and by the tenant under a Net and Modified Gross leases. Economic theory indicates that the best party to bear the risk-the tenant or the landlord-will be determined by which party is the more risk tolerant. For example, if the landlord is the more risk tolerant, then we would expect the market to adopt Full Service leases, thus allowing the tenants to avoid the risk of unexpectedly high energy costs.

Asymmetric information-meaning that either the landlord or tenant has better information concerning the likely energy costs-raises additional issues for the desired contracting outcome. For example, if the landlord can estimate the likely energy costs with greater precision than can the tenant, then this creates be a further reason for the landlord to bear the risk as under a Full Service contract. On the other hand, when the tenant can control the amount of energy use, and would significantly expand the use under a Full Service or Modified Gross contract, then a Net contract may be the preferred contract outcome.

The implication is that Net lease contracts are commonly judged to be the most conducive for energy efficiency because they provide tenants the greatest incentive to limit their energy use. We will see in Section 3 below, however, that Net contracts are not a dominant outcome for office building leases and that they are actually quite uncommon for large, multi-tenant, office buildings in city centers. It is thus worth noting here several factors that limit the use of Net leases:

1. Net lease contracts will not be effective where metering of individual spaces is not available. Direct metering is limited because it is expensive and is even illegal in certain jurisdictions.

2. Net lease contracts place all the risk of uncertain energy costs on the tenant. For situations in which the main uncertainty concerns the market price of energy, as opposed to the physical amount used by the tenant, a Full Service contract may be preferred if the landlord is more tolerant.

3. Net lease contracts may limit the incentive of a landlord to carry out energy efficient building improvements, since the benefits of lower energy costs would then accrue, at least initially, to the current tenants. 


\subsubsection{Capital Investments Under Alternative Lease Contracts}

The preceding discussion has taken as given the building's energy efficiency. Landlords, of course, may carry out capital investments that would improve the building's level of energy efficiency. In this section, we consider the incentives landlords receive to carry out such investments.

Net present value (NPV) is generally the preferred economic criterion for investment decisions. Applied to an investment to improve a building's energy efficiency, NPV would be computed as the present value of the savings in future energy payments minus the investment cost. The NPV criterion has the desirable feature that it provides the landlord an incentive to carry out investments as long as the direct benefits exceed the direct costs. Of course, there may also be societal benefits to carrying out energy efficient investments-for example, to reduce global warming-and in these cases it may be useful for governments to provide additional financial incentives. It is also worth nothing that rules of thumb such as Payback Period-the number of years required to recover the initial investment costs-are often used as approximations to a full NPV evaluation.

Whatever the detailed computational format, the standard application of NPV techniques assumes that the landlord alone pays the costs and receives the benefits of the investment. We have seen, however, that both the costs and benefits of energy investments may fall on the tenants depending on the particular lease contract. The expected investment incentives by contract form can be summarized as follows:

- Full Service Lease. Under Full Service leases, all the costs and benefits of energy investments accrue to the landlord alone. Full Service leases are thus consistent with the incentives provided landlords who apply an NPV criterion, and thus should provide the optimal level of energy efficient investment levels.

- Net Lease. Under Net leases, the tenant both receives the benefits of reduced energy costs and pays the amortized costs of the investment. Under ideal conditions, the landlord and tenant will agree on the desired energy efficient investments, and thus the same investments will be carried out as under a Full Service lease. One limiting factor, however, is that the tenant's occupancy horizon may not equal the expected economic life of the capital investment. A second limiting factor is that the time patterns of the amortized costs and the energy-saving benefits may differ. If, for example, the tenant has a relatively short horizon and the amortization payments exceed the energy-saving benefits over this period, then the tenant may object to the capital investment even when it is NPV positive. A further issue also arises in the common case when the tenant move outs before the capital investment is fully amortized. In this case, the 
landlord will have to convince the new tenant to pay a higher space rent based on lower expected energy costs. If the landlord fears she will be unable to achieve a higher rent, then she may be reluctant to carry out the investment in the first place. On the other hand, assuming the investment is NPV positive and that the landlords of comparable buildings carry out such investments, then a landlord who fails to make the investment runs the risk of lowing potential tenants and receiving only lower rents.

- Modified Gross Lease. Modified Gross leases are comparable to Net leases in that tenants receive the benefits of reduced energy costs, and thus, at least to a first approximation, landlords face the same incentives with regard to energy efficient investments.

Table 10 presents the contractual structures that are represented in the CoStar data. As shown, we are missing information on the dominant leasing structure for more than $57 \%$ of the transactions. For those buildings for which we have leasing structure, the dominant types are the full service gross with $18.8 \%$ of transactions, where the landlord pays all the energy costs and the tenants pay a pro rata share based on their percentage of leased space, and some form of triple net lease, $18.04 \%$ where the tenant pays the costs.

Table 10: Lease Contract Types in the COSTAR Office Building Transaction Data This table presents the primary lease contracting methods for allocating the utility expenses (water, natural gas, and electricity expenses) to tenants in the COSTAR building that traded in armslength-transactions between 1999 and 2010. These data were obtained by merging the COSTAR rental data with the COSTAR Transactions data.

\begin{tabular}{lrrrr}
\hline Contract Type & Frequency & Percent & Cumulative Frequency & Cumulative Percent \\
\hline Full Service Gross & 2768 & $18.29 \%$ & 2768 & $18.29 \%$ \\
Modified Gross & 874 & $5.78 \%$ & 3642 & $24.07 \%$ \\
Triple Net & 2626 & $17.35 \%$ & 6268 & $41.42 \%$ \\
Missing & 8865 & $58.58 \%$ & 15133 & $100.00 \%$ \\
\hline
\end{tabular}

There is also important geographic structure to the location of office buildings that rely on different leasing structures. For example, as shown in the Appendix in Figure 3 and Figure 4, the Net Leases contracts predominate in the South Bay (Silicon Valley) area where office buildings often include an important component of tenants characterized by high electricity consumption required for "clean rooms" and computers. Net lease are also found in other peripheral office market areas in both the San Francisco and Los Angeles markets. The full service and modified gross leases are found primarily in central business district areas in the 
Bay Area and Los Angeles office markets.

\subsection{Empirical Tests}

At least one of the implications of the preceding discussion is that energy use in Triple Net buildings would be lower reflecting the direct incentive of tenants to minimize their energy bill. Although we cannot directly test this hypothesis, we consider two specifications to explore these effects: an estimation of the forward looking asset pricing specification defined by Equation (2) with controls introduced for the lease contracting structure of the building; a re-estimation of the total operating expenses relationship again with controls for the leasing structure.

As shown in Table 11, the results for the valuation expression are very similar to those reported for specifications for Equation (2), reported in Table 7, that did not include controls for the lease contracting structure of the building. Given the small sample size, the slope of the power forward curve has a statistically significant and positive effect on the price per square foot but only at the $10 \%$ level of statistical significance. The other energy factor prices no longer have statistically significant effects on prices. The weather effects retain their strong and statistically significant effects on log price per square foot even after controls for fixed effects, although their effects of variance in minimum and maximum temperatures appear to countervail each other. Again, the importance of the Equation (2) specification for asset prices is borne out with the results for net operating income, the capitalization rate, total expenses per square foot are all economically and statistically significantly associated with log transaction prices per square foot. Again, the indicator variable for an Energy Star certification at time of sale contributes no additional explanatory power in this regression, nor does a specification that accounts for the period in which the Energy Star certification was received.

The introduction of the indicator variables for predominance of Full Service and Modified Full Service Leases in the building is shown to have a statistically and significantly negative effect on transaction prices relative to the omitted category of Triple Net Leases. Indeed, this result appears to suggest, as expected from the incentive structure of Full Service and

Modified Full Service Leases that contractual inducements for tenants to minimize the utility costs of their space-use does appear to affect building value. Since utility costs are paid as a pro rata share in Full Service and Modified Full Service Leases, individual tenants have little incentive to minimize their utility consumption. This differential incentive structure appears to have important effects on transaction values at the margin.

In Table 12, we report the results of re-estimating the log of total operating expenses 
Table 11: Regression Results for Office Buildings that Sold 2001 through 2010

This table presents the regression results for the log price per square foot at sale buildings that sold in arm-length-transactions between 2001 and 2010. The dependent variable is the log price per square foot and it is regressed on energy price and weather effects, building characteristics, leasing characteristics, and the Energy Star rating status of the building at the time of sale. These data were obtained from the COSTAR Transactions data base. The energy forward curve data was estimated using data from Platts and NYMEX and the weather data was obtained from Wolfram Schlenker.

\begin{tabular}{|c|c|c|c|c|}
\hline Variable & $\begin{array}{l}\text { Parameter } \\
\text { Estimate }\end{array}$ & $\begin{array}{r}\text { Standard } \\
\text { Error }\end{array}$ & $\begin{array}{l}\text { Parameter } \\
\text { Estimate }\end{array}$ & $\begin{array}{r}\text { Standard } \\
\text { Error }\end{array}$ \\
\hline Intercept & 5.418 & 0.248 & $5.416^{* * *}$ & 0.249 \\
\hline Six month lag price of the $1-12$ month & & & & \\
\hline forward contract at sale by transaction hub & 0.004 & 0.003 & 0.004 & 0.003 \\
\hline Six month lag slope of the power forward curve & $0.016^{*}$ & 0.008 & $0.015^{*}$ & 0.008 \\
\hline Six month lag price of the $1-12$ month & & & & \\
\hline natural gas forward contract at sale & -0.007 & 0.013 & -0.005 & 0.013 \\
\hline Six month lag slope of the natural gas forward curve & -0.100 & 0.080 & -0.095 & 0.080 \\
\hline Standard Deviation of 12 Month Maximum Temperature & $-0.011^{* * *}$ & 0.003 & $-0.011^{* * *}$ & 0.003 \\
\hline Standard Deviation of 12 Month Minimum Temperature & $0.011^{* * *}$ & 0.003 & $0.010^{* * *}$ & 0.003 \\
\hline Standard Deviation of 12 Month Precipitation & 0.036 & 0.633 & 0.039 & 0.632 \\
\hline Number of floors & 0.000 & 0.003 & 0.001 & 0.003 \\
\hline Age of the Building & $-0.004^{* * *}$ & 0.001 & $-0.004^{* * *}$ & 0.001 \\
\hline Building square footage & 0.000 & 0.001 & 0.000 & 0.001 \\
\hline Typical floor area square footage & 0.007 & 0.007 & 0.007 & 0.007 \\
\hline Indicator variable for renovation prior to sale & -0.014 & 0.138 & -0.012 & 0.138 \\
\hline Indicator variable for class A buildings & $0.203^{* * *}$ & 0.034 & 0.199 & 0.034 \\
\hline Indicator Variable for Multi-Tenant Building & 0.013 & 0.054 & 0.013 & 0.054 \\
\hline Market capitalization rate at year of sale & $-0.098^{* * *}$ & 0.011 & $-0.098^{* * *}$ & 0.011 \\
\hline Total expenses per square foot at year of sale & $-0.199 * * *$ & 0.047 & $-0.199^{* * *}$ & 0.047 \\
\hline Net operating income per square foot at year of sale & $0.501^{* * *}$ & 0.045 & $0.502^{* * *}$ & 0.045 \\
\hline Predominate Lease Structure: Full Service Gross & $-0.154^{* * *}$ & 0.039 & $-0.154^{* * *}$ & 0.039 \\
\hline Predominant Lease Structure: Modified Gross & $-0.213^{* * *}$ & 0.056 & $-0.214^{* * *}$ & 0.056 \\
\hline Indicator variable for Energy Star rating by time of sale & & & 0.077 & 0.079 \\
\hline Indicator variable for Energy Star rating by time of sale (2003-2005) & -0.004 & 0.001 & & \\
\hline Indicator variable for Energy Star rating by time of sale (2006-2009) & -0.009 & 0.292 & & \\
\hline Market Fixed Effects & Yes & & Yes & \\
\hline Year Fixed Effects & Yes & & Yes & \\
\hline Clustered Standard Errors (Sale date and Market) & Yes & & Yes & \\
\hline$R^{2}$ & 0.668 & & 0.667 & \\
\hline Number of Observations & 558 & & 558 & \\
\hline
\end{tabular}


Table 12: Regression Results for Total Operating Expenses for Office Buildings that Sold 2001 through 2010

This table presents the regression results for the total operating expenses of office buildings that sold in arm-length-transactions between 2001 and 2010. The dependent variable is the log operating expense per square foot at sale and it is regressed on energy price and weather effects, building characteristics, leasing characteristics, and the Energy Star rating status of the building at the time of sale. These data were obtained from the COSTAR Transactions data base. The energy forward curve data was estimated using data from Platts and NYMEX and the weather data was obtained from Wolfram Schlenker.

\begin{tabular}{|c|c|c|}
\hline Variable & $\begin{array}{l}\text { Parameter } \\
\text { Estimate }\end{array}$ & $\begin{array}{r}\text { Standard } \\
\text { Error }\end{array}$ \\
\hline Intercept & $1.304^{888}$ & 0.188 \\
\hline Six month lag price of the $1-12$ month & & \\
\hline forward contract at sale by transaction hub & -0.001 & 0.002 \\
\hline Six month lag slope of the power forward curve & 0.004 & 0.007 \\
\hline Six month lag price of the $1-12$ month & & \\
\hline natural gas forward contract at sale & -0.015 & 0.012 \\
\hline Six month lag slope of the natural gas forward curve & -0.015 & 0.054 \\
\hline Standard Deviation of 12 Month Maximum Temperature & -0.005 & 0.003 \\
\hline Standard Deviation of 12 Month Minimum Temperature & $0.008^{* *}$ & 0.003 \\
\hline Standard Deviation of 12 Month Precipitation & $1.150^{* *}$ & 0.562 \\
\hline Number of floors & $0.012^{* * *}$ & 0.003 \\
\hline Age of the Building & 0.000 & 0.001 \\
\hline Building square footage & -0.002 & 0.001 \\
\hline Typical floor area square footage & -0.006 & 0.006 \\
\hline Indicator variable for renovation prior to sale & $-0.152^{*}$ & 0.091 \\
\hline Indicator variable for class A buildings & 0.145 & 0.034 \\
\hline Indicator Variable for Multi-Tenant Building & $0.257^{* * *}$ & 0.045 \\
\hline Predominate Lease Structure: Full Service Gross & 0.015 & 0.040 \\
\hline Predominant Lease Structure: Modified Gross & -0.050 & 0.056 \\
\hline Indicator variable for Energy Star rating by time of sale & -0.077 & 0.070 \\
\hline Market Fixed Effects & Yes & \\
\hline Year Fixed Effects & Yes & \\
\hline Clustered Standard Errors (Sale date and Market) & Yes & \\
\hline$R^{2}$ & 0.321 & \\
\hline Number of Observations & 953 & \\
\hline
\end{tabular}


on market and building characteristics when we introduce controls for the dominant lease contracting structure of the building. As shown, overall, the results are similar to those discussed in the preceding sections and we find that multi-tenant building are economically and statistically associated with higher total operating expenses. Interestingly, the controls for the Full Service and Modified Full Service Leases are not associated with the level of total operating expenses per square foot nor is the Energy Star Certification. Given the small sample size, it is difficult to draw strong conclusions about the relationship between building costs and the leasing structure of buildings. Nor it is possible, to clearly differentiate the cost effects of leasing structure of the office buildings in our sample.

\section{Conclusions}

This paper presents an empirical analysis of the relationship between energy factor markets, leasing structures and the transaction prices of office buildings in the U.S. We employ a large sample of 15,133 office building transactions that occurred between 2001 and 2010. In addition to building characteristics, we also include information on the operating expenses, the net operating income, and the capitalization rates at sale to estimate an asset pricing model for commercial office real estate assets. A further set of important controls in our analysis is the one-to-twelve month forward contract prices and the shape of the forward contract price curve, using auction data from the major electricity trading hubs in the U.S. and from the Henry Hub for natural gas. We also include weather metrics in the form of the variance in the last twelve months of minimum and maximum temperature and precipitation from each building's sale date. Our final set of controls includes information on the dominant leasing structures in the buildings. Our empirical results suggest that Energy Star labels do not explain additional variance in property prices once the key asset pricing factors of expenses, income and capitalization rates are included. Energy factor market prices, the shape of the energy price curves, and weather metrics are consistently shown to be statistically significant determinants of office building transaction prices, suggesting that commercial office building prices are likely to be exposed to shocks in these markets. This finding has important implications for underwriting commercial mortgage default risk. 


\section{A Appendix}

\section{A.1 Geographic Structure of the Transactions Data}

\section{A.2 Weather Data Construction}

The weather data were obtained from Wolfram Schlenker at Columbia University. These data are based on the same rectangular grid system underling PRISM that covers the contiguous United States ${ }^{18}$ It consists of 1405 grids in the longitude direction and 621 grids in the latitude dimension, space equidistant 1/24 degree steps (about 2.5 miles). The data are matched to the centroid of each grid point to the fips codes of all counties in the United States. There are 471,159 grid points with non-missing data in the PRISM data where the centroid is matched to lie within a county. These are displayed in shades of grey in Figure 7. There were 390,864 grid points that had missing values in PRISM and the centroid could not be matched to a fips code. These grids are display in blue in Figure 7. There are 10,480 grid points with non-missing valued in PRISM whose centroid could not be matched to a county. These are primarily around the border of the United States as well as over water bodies like the Chesapeake or San Francisco Bay. They are displayed in red in Figure 7. There were also 2 grids that had missing values in PRISM but whose entroids could be matched to a county. They are displayed in green in Figure 7 and can be found at the shoreline of the Great Lakes.

The data include the minimum and maximum temperature (Celsius), total precipitation (cm) for each day of a year for all of the 471159 grids in the United States from 1950 through 2010. These data are interpolated from PRISMs monthly weather station averages to daily data and we aggregate them back into monthly data for our analysis. We associate the past twelve months of weather data for each building in the COSTAR data with the weather data associated with the nearest grip point in the Schlenker, et al. data.

\section{A.3 Energy Data Construction}

We extract the energy forward curve pricing from the forward contract auctions for electricity and from the futures contracts auctions for natural gas. We follow Benth, Koekebakker, and Ollmar (2007), Benth, Cartea, and Kiesel (2008), Geman and Roncoroni (2006) and Riedhauser (2000), in the construction of these curves.

\footnotetext{
${ }^{18} \mathrm{http}$ ///www.prism. oregonstate.edu/
} 


\section{A.3.1 Forward Market for Power (Electricity)}

The forward market for power is organized around the trading of different standard packages covering the on-peak and off-peak periods. Trading occurs for delivery hubs located at the Eastern-Central regions and delivery hubs located in the Western region of the continental United States. The Easter-Central standard forward package covers the following markets: New England, New York (several hubs), Ontario, PJM, MISO, ERCOT South, Into Entergy, Into Southern and Into TVA. The Western packages cover NP15 and SP15 among others. Packages for the Eastern-Central hubs differ from those traded for the Western hub on two dimensions: the way on-peak and off-peak are defined and the delivery months of the forward packages.

We compute the standard on-peak forward packages in Eastern and Central markets are 5x16 packages (5 days per week and 16 hours per weekday from 7:00 Am to 22:59 PM), which include power delivered during on-peak hours on weekdays and exclude weekends and holidays.$^{19}$ Similarly, on-peak forward packages in Western markets are $6 \times 16$ packages, which include power delivered during the 16 on-peak hours each day Monday through Saturday and exclude Sundays and holidays. The off-peak standard packages, the forward market trade $5 \times 8$ ( 5 days per week and 8 hours per day) plus a $2 \times 24$ package, this includes power for delivery during the eight off-peak hours each weekday, plus all 24 hours (around the clock) on weekends. The standard off-peak forward package for the Western markets is a $6 \times 8$ delivery block plus a 1x24 delivery block, this includes power for delivery during the eight off-peak hours Monday through Saturday plus all 24 hours (around the clock) on Sunday.

For the Eastern-Central markets, on-peak and off-peak contracts are formulated for the prompt month (nearest contract), second month, third month, and balance-of-the-year in seasonal or single month packages, two full years in seasonal or single-month packages and two subsequent calendar year packages. Separate seasonal and single-month packages include the January-February winter package, the March-April spring package, May, June, the JulyAugust summer package, September and the fourth quarter (from October to December).

The following example illustrates, for a given trading date, the typical term-structure of contracts for packages traded in the Eastern-Central hubs. Suppose the today's date is 5/15/2009. At this time, the market is trading the following forward packages:

- 2009 - June-2009 (prompt month), July-2009 (second month), August-2009 (third month), September-2009 (single month package), fourth-quarter 2009,

- 2010 - January-February-2010 (winter package), March-April-2010 (spring package), May-2010 (single month package), June-2010 (single month package), July-August-

\footnotetext{
${ }^{19}$ Power market holidays are defined by the North American Electric Reliability Corp. (NERC).
} 
2010 (summer package), September-2010 (single month package), fourth-quarter 2010,

- 2011 - January-February-2011 (winter package), March-April-2011 (spring package),

- May-2011 (single month package), June-2011 (single month package), July-August2011 (summer package), September-2011 (single month package), fourth-quarter 2011, - 2012 - year-2012 (calendar year package), 2013 - year-2013 (calendar year package).

For the Western markets, on-peak and off-peak packages are formulated for the prompt month, second month, balance of the year in quarters, two full years in quarters, and two subsequent calendar year packages.

As before, suppose the today's date is 5/15/2009. At this time, the market is trading the following forward packages for a Western hub:

- 2009 - June-2009 (prompt month), July-2009 (second month), August-2009 (third month), third-quarter 2009 (July-September package), fourth-quarter 2009 (OctoberDecember package),

- 2010 - first-quarter 2010 (January-March package), second-quarter 2010 (April-June package), third-quarter 2010 (July-September package), fourth-quarter 2010 (OctoberDecember package),

- 2011 - first-quarter 2011 (January-March package), second-quarter 2011 (April-June package), third-quarter 2011 (July-September package), fourth-quarter 2011 (OctoberDecember package),

- 2012 - year-2012 (calendar year package),

- 2013 - year-2013 (calendar year package),

A significant portion of transactions are realized over-the-counter (OTC). Transactions also occur on specialized exchanges such as the IntercontinentalExchange (ICE). Often trading parties take their existing OTC transactions for clearing into ICE. This mechanism mitigates counterparty risk since parties are now at arms-length and are subject to margin calls as prices for the forward packages fluctuate.

The energy volume for a typical package is $50 \mathrm{MWh}$ (Megawatt-hour) times the number of on-peak or off-peak hours depending on the type of package. If for example, the parties are trading an on-peak September-2011 contract delivering into the PJM Western hub. Assuming that there are 22 NERC weekdays for this month. The total volume for such a package would is then calculated as $(50 \times 22 \times 16) \mathrm{MWh}$.

Parties engage in financial settlement a few days after the ending date of the package. As in the example above, the settlement for the September-2011 package occurs in the beginning of October-2011. The long party receives (pays) the difference between the floating price (calculated, in this case, as the arithmetic average of the arithmetic averages of the hourly 
on-peak real-time prices posted by PJM Interconnection, LLC, on their official website) and the agreed forward price at the time of contracting. ${ }^{20}$

\section{A.3.2 Dataset - Platts-Ice Forward Curve}

In this section we describe the source of data for constructing our power forward price level and slope database. We contracted the raw data for Platts (the data vendor) and worked out a daily forward curve for power on on-peak and off-peak comprising selected trading hubs serving large cities in The United States.

Platts gathers information on the power forward market from active brokers and traders and through the non-commercial departments (back offices) of companies. Since October 2007 this information is complemented with the IntercontinentalExchange (ICE) quotes to form the Platts forward market power daily assessment. Since more liquid locations and shorter term packages trade more on ICE, while less liquid locations and longer term packages trade more over-the-counter (OTC), Platts is able to combine these sources to build a comprehensive picture of the forward market. Details of the methodology are described in the Platts Methodology and Specification Guide - Platts-ICE electricity Forward Curve (North America).

In our analysis, we selected a subset of trading hubs corresponding to large urban populated areas covering both the eastern, western, southern regions of the United States. The following table describes these power hubs, the related urban areas referenced by the hub, and the closest wholesale natural gas trading hub.

Figure 6 presents the geographic location of all the the power hubs in the U.S. We select a sub-set of hubs based on data availability for options and forward contracts from Platts and by our requirement to account for the power forward prices for all metropolitan areas with 150,000 employees in Finance, and Professional and Business Services (the major office categories). ${ }^{21}$ As shown, in the Figure there is considerable regional variation in the level of power forward prices and in their time series dynamics. The hub locations correspond to the nodal structure of the natural gas pipeline in the U.S. and to the location of the major population centers in the U.S.

Raw data from Platts is formatted with single entries for each forward package (see the "Forwards Market for Power" section above). For a given trading date, a power hub, and a type of contract - on peak and off-peak - there are single entries for the mark-to-market price for each forward package. This scheme characterizes a whole term-structure of power

\footnotetext{
${ }^{20}$ We refer the reader to the Intercontinental Exchange website for more details on how the contracts are traded and settled.

${ }^{21}$ Bureau of Labor Statistics, Employment Hours and Earnings, State and Metro Area, http: //www.bls . gov/sae/data.htm
} 
prices for a given trading date. The following table describes for each hub and contract type the time series of the related forward curves.

Table 13: The Earliest and Latest Trading Dates for the Power Hubs This table presents the periods for which we have data on the forward and spot prices for each electricity hub.

\begin{tabular}{lrrr}
\hline Contract Type & Region Name & Minimum Trade Date & Maximum Trade Date \\
\hline on-peak & East New York Zone J & $1 / 2 / 2002$ & $4 / 23 / 2010$ \\
on-peak & ERCOT & $1 / 2 / 2002$ & $4 / 27 / 2010$ \\
on-peak & Mass Hub & $8 / 30 / 2002$ & $4 / 23 / 2010$ \\
on-peak & NI Hub & $1 / 2 / 2002$ & $4 / 23 / 2010$ \\
on-peak & North Path 15 & $12 / 31 / 2001$ & $4 / 23 / 2010$ \\
on-peak & PJM West & $3 / 5 / 2001$ & $4 / 23 / 2010$ \\
on-peak & South Path 15 & $12 / 31 / 2001$ & $4 / 23 / 2010$ \\
on-peak & Into Cinergy & $3 / 1 / 2001$ & $10 / 23 / 2010$ \\
on-peak & Into Entergy & $3 / 1 / 2001$ & $10 / 23 / 2010$ \\
on-peak & Into Southern & $12 / 1 / 2005$ & $10 / 23 / 2010$ \\
on-peak & Into TVA & $1 / 1 / 2002$ & $10 / 23 / 2010$ \\
on-peak & Mid Columbia & $3 / 1 / 2001$ & $10 / 23 / 2010$ \\
on-peak & Palo Verde & $3 / 1 / 2001$ & $10 / 23 / 2010$ \\
\hline off-peak & East New York Zone J & $1 / 31 / 2007$ & $4 / 27 / 2010$ \\
off-peak & Mass Hub & $2 / 7 / 2007$ & $4 / 23 / 2010$ \\
off-peak & NI Hub & $1 / 31 / 2007$ & $4 / 23 / 2010$ \\
off-peak & $5 / 31 / 2006$ & $4 / 23 / 2010$ \\
off-peak & North Path 15 & $1 / 31 / 2007$ & $4 / 23 / 2010$ \\
off-peak & PJM West & $5 / 31 / 2006$ & $4 / 23 / 2010$ \\
off-peak & South Path 15 & $3 / 1 / 2001$ & $10 / 23 / 2010$ \\
off-peak & Into Cinergy & $3 / 1 / 2001$ & $10 / 23 / 2010$ \\
off-peak & Into Entergy & $12 / 1 / 2005$ & $10 / 23 / 2010$ \\
off-peak & Into Southern & $1 / 1 / 2002$ & $10 / 23 / 2010$ \\
off-peak & Into TVA & $3 / 1 / 2001$ & $10 / 23 / 2010$ \\
off-peak & Mid Columbia & $3 / 1 / 2001$ & $10 / 23 / 2010$ \\
\hline & Palo Verde & &
\end{tabular}

After inspecting the raw data, we noted the following:

1. We did not find any significant gaps on trade dates for all time series.

2. The time series for on-peak New York Zone-J has gaps on the term-structure from the beginning of the time series $1 / 2 / 2002$ to $1 / 11 / 2005$. Consequently, we discarded these raw entries when calibrating instantaneous volatilities. 
3. The ERCOT (all zones) time series has data up to $11 / 25 / 2008$. Consequently, we extended the time series for ERCOT by appending the ERCOT-South time series starting in $11 / 26 / 2008$.

4. We discarded raw entries with trade dates later than the beginning of the delivery period. For example, we found on 3/6/2008 a quote for the on-peak East NY ZnJ Mar/Apr 2008 package. Note that on this trade is already into the delivery period of the contract which starts on $1 / 3 / 2008$. Though these types of trades are valid, the quote corresponds to parties trading on information related to the balance of the delivery package. Consequently, since the structure of the contract is now different from the original package, we discard these entries.

5. The length of the forward curve increases for more recent years. We illustrate this by showing below the maximum number of months out by trading year for the on-peak PJM Western hub and NP15 hub.

The raw data from Platts contains a field called "symbol" indicating the type of contract, the package, the power hub, and the year related to the package. The "symbol" field is coded with 7 characters with the following structure and the last two characters is a two digit code for the hub name. The other codes include:

The following describes Platts coding for the sub-fields seasonal package and the Contract Length:

\section{A.3.3 Futures Market for Natural Gas}

There is a very active market for natural gas in The United States. Following deregulation of the wholesale market for natural gas in mid 1990's, the New York Mercantile Exchange (NYMEX) launched the trading of monthly futures contracts with similar characteristics to those of crude oil. The standard NYMEX natural gas futures contracts specify physical delivery of 10,000 MMBtu (millions of British thermal unit) ratably delivered into Henry Hub - Louisiana. Until early 2000' NYMEX provided monthly contracts covering maturities about 36 months out. More recently, the range of maturities has been extended and it now covers more then six years (72 months) on a monthly basis. The NYMEX website provides more details on how the contracts are traded and the rules for settlement.

The following graph shows NYMEX's prompt month (nearest contract) daily quotes starting in 2005.

There is an extensive network of natural gas pipelines connecting the production basins to

large consumption areas (mainly large populated urban centers). Wholesale physical natural gas trading occurs in different hubs distributed in the continental United States. These hubs 
Table 14: The Maximum Number of Months out by Trading Year for the On-peak PJM Western and NP15 Hubs

This table shows that the length of the forward curve has increased for more recent years.

\begin{tabular}{lrr}
\hline Region Name & Year of Trade Date & maximum Month Out \\
North Path 15 & 2001 & 35 \\
North Path 15 & 2002 & 41 \\
North Path 15 & 2003 & 41 \\
North Path 15 & 2004 & 41 \\
North Path 15 & 2005 & 59 \\
North Path 15 & 2006 & 59 \\
North Path 15 & 2007 & 59 \\
North Path 15 & 2008 & 59 \\
North Path 15 & 2009 & 59 \\
North Path 15 & 2010 & 59 \\
\hline PJM West & 2001 & 41 \\
PJM West & 2002 & 41 \\
PJM West & 2003 & 41 \\
PJM West & 2004 & 41 \\
PJM West & 2005 & 41 \\
PJM West & 2006 & 47 \\
PJM West & 2007 & 59 \\
PJM West & 2008 & 59 \\
PJM West & 2009 & 59 \\
PJM West & 2010 & 59 \\
\hline
\end{tabular}

Table 15: The Symbol Codes from Platts

This table presents the symbol code keys from Platts that are used to identify the class of forward and spot contracts and the location of the trading hub.

\begin{tabular}{lrrr}
\hline Position & sub-field size & Sub-field indicator & comments \\
\hline 1-Jan & 1 & on-peak / off-peak & "F" for on-peak and "O" for off-peak \\
3-Feb & 2 & seasonal package & see table below \\
5-Apr & 2 & power hub name & see table below \\
7-Jun & 2 & package year & - \\
\hline
\end{tabular}


Table 16: Codes for the Sub-Field Seasonal Packages and their Contract Length This table presents the codes used by Platts to identify seasonal packages, their start and end dates, and the forward contract length.

\begin{tabular}{lrrrr}
\hline Contract Code & Contract Description & Start Month & End Month & contract Length \\
\hline AA & (seasonal package) & & & \\
AB & January & 1 & 1 & 1 \\
AC & February & 2 & 2 & 1 \\
AD & March & 3 & 3 & 1 \\
AE & April & 4 & 4 & 1 \\
AF & May & 5 & 5 & 1 \\
AG & June & 6 & 6 & 1 \\
AH & July & 7 & 7 & 1 \\
AI & August & 8 & 8 & 1 \\
AJ & September & 9 & 9 & 1 \\
AK & October & 10 & 10 & 1 \\
AL & November & 11 & 11 & 1 \\
AN & December & 12 & 12 & 1 \\
AP & January-February & 1 & 2 & 2 \\
AT & March-April & 3 & 4 & 2 \\
AY & July-August & 7 & 8 & 2 \\
Q1 & Year & 1 & 12 & 12 \\
Q2 & First Quarter & 1 & 3 & 3 \\
Q3 & Second Quarter & 4 & 6 & 3 \\
Q4 & Third Quarter & 7 & 9 & 3 \\
\hline
\end{tabular}


are key points in the pipeline grid characterized by either being interconnections between major pipelines and/or access points to public utility gas companies. Of all those hubs, Henry Hub is the benchmark for price quotation. Henry Hub's importance stems from both as being an interconnecting point for multiple pipelines and as being the most liquid point for trading spot and futures contracts. Prices for other hubs (spot and OTC forwards) are typically quoted as a basis to Henry Hub. These basis quotes are a very small fraction of the full benchmark quote. 
Figure 1: EPA Energy Star Rated Buildings Located in the Los Angeles, Riverside, and San Diego Areas

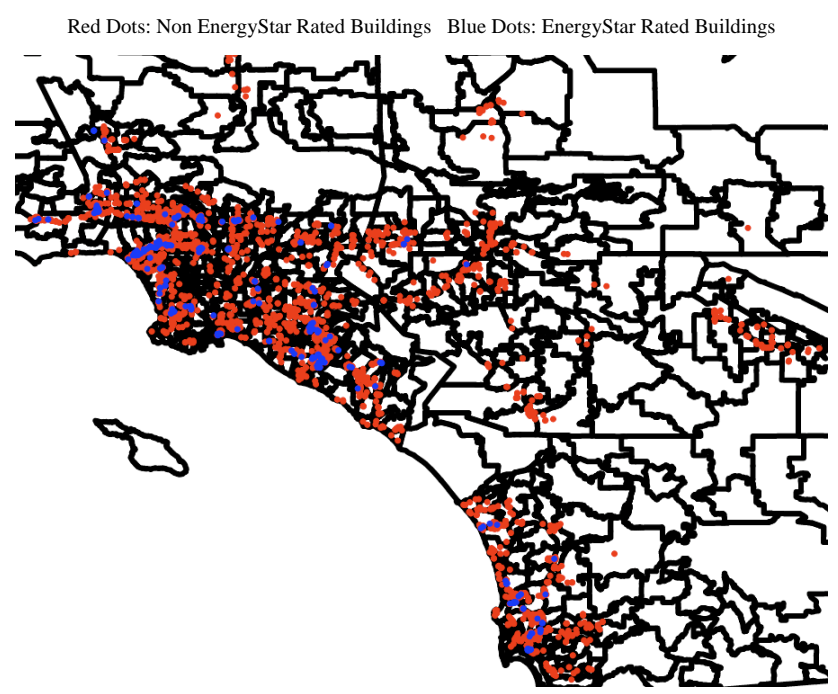

Figure 2: EPA Energy Star Rated Buildings Located in the San Francisco, East Bay, San Jose, and Sacramento Market Area

Red Dots: Non EnergyStar Rated Buildings Blue Dots: EnergyStar Rated Buildings

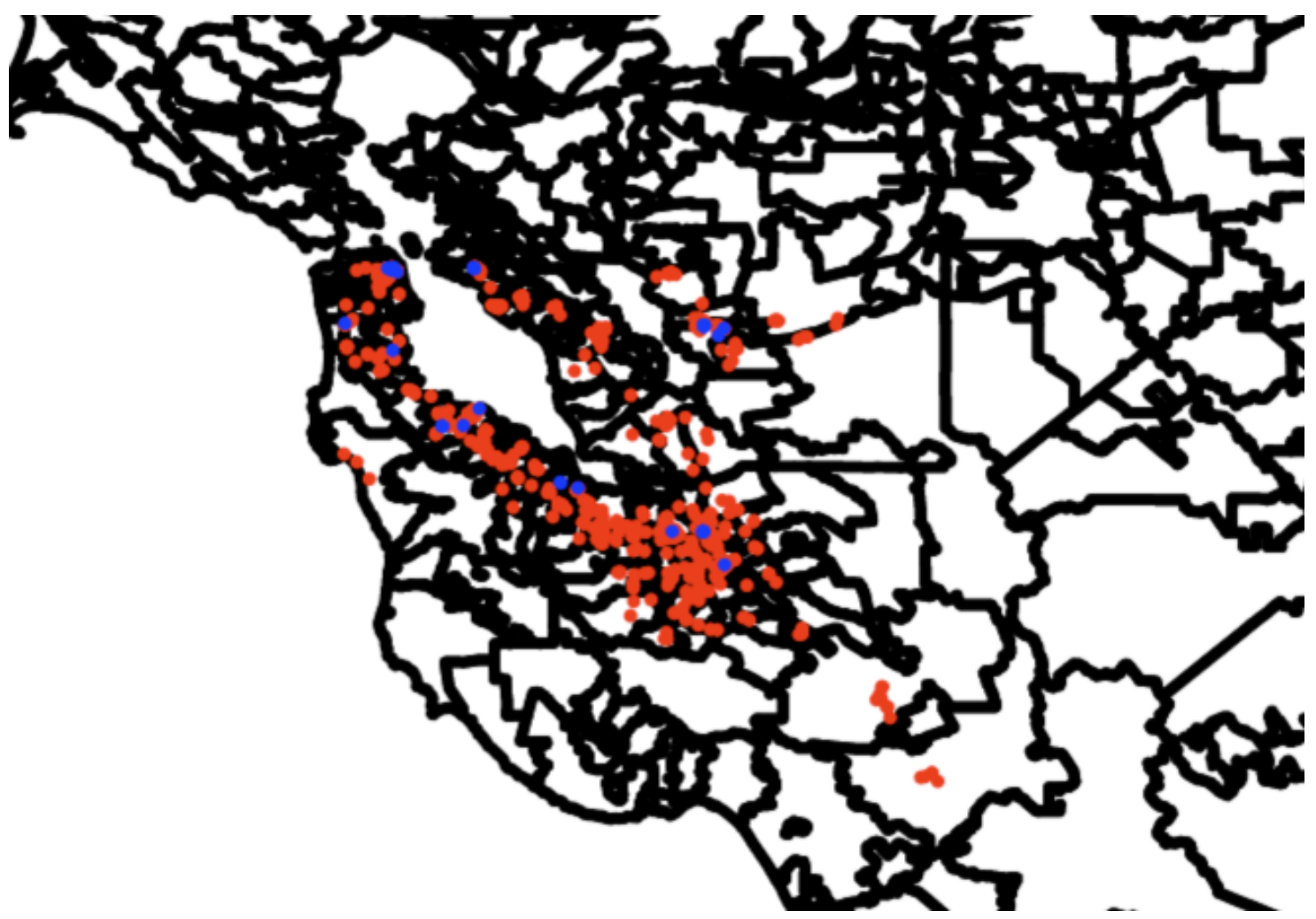


Figure 3: Lease Contract Types for Building Locations in San Francisco, East Bay, San Jose, and Sacramento Area

Green Dots: Full Service Leases Blue Dots: Modified Gross Leases Red Dots: Triple Net Leases

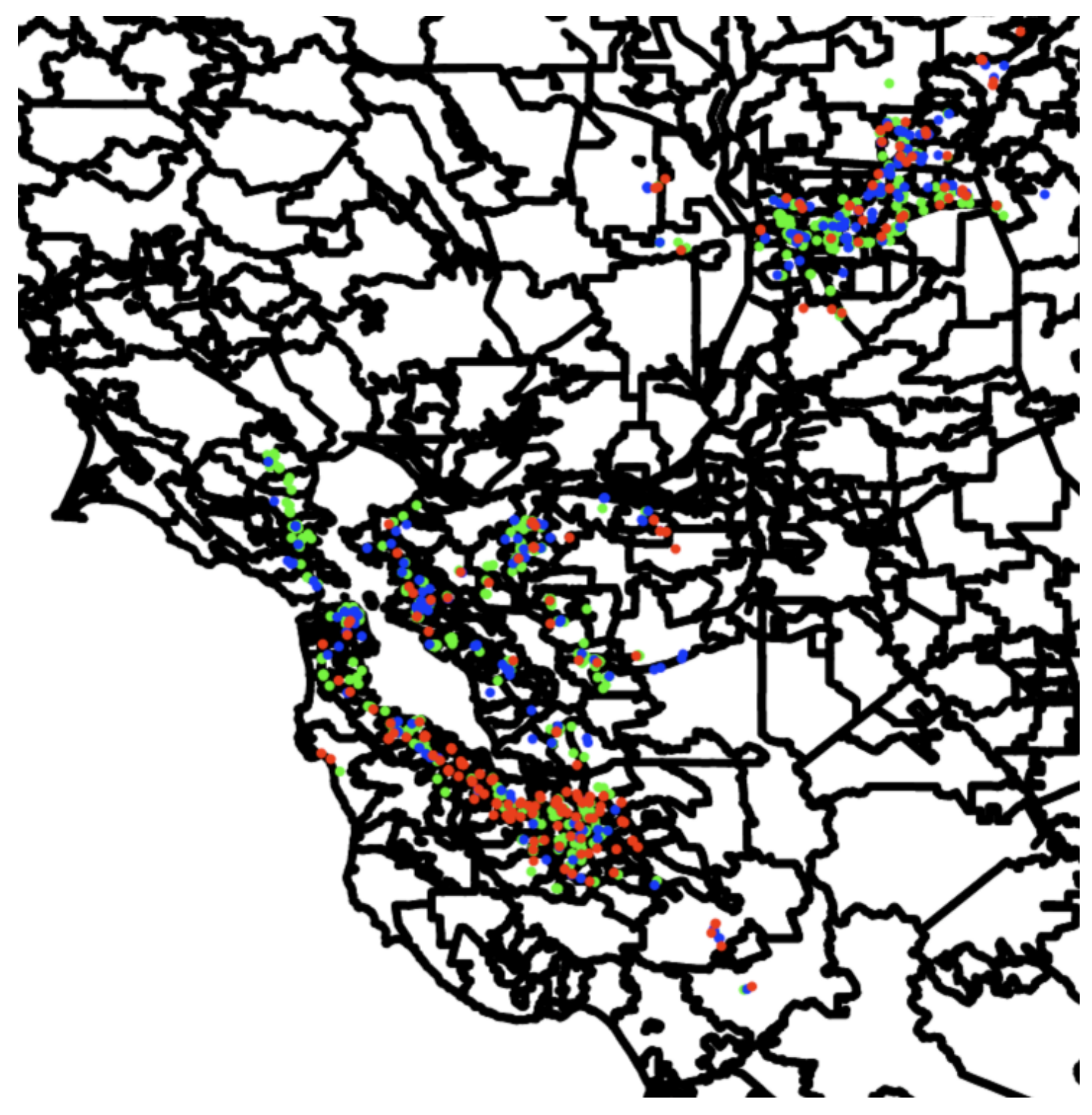


Figure 4: Lease Contract Types for Building Locations in Los Angeles, Riverside, and San Diego Area

Green Dots: Full Service Leases Blue Dots: Modified Gross Leases Red Dots: Triple Net Leases

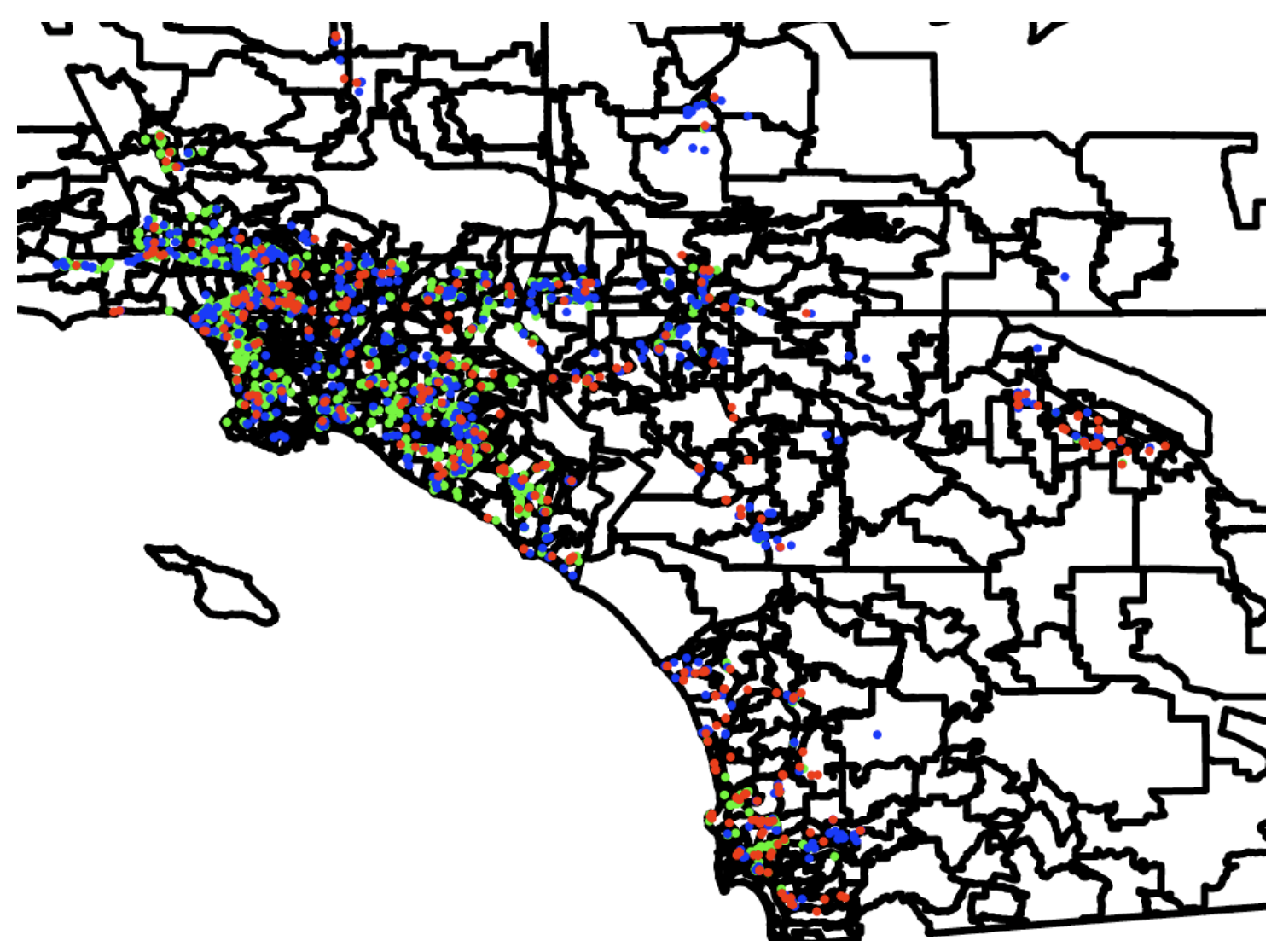


Figure 5: Geographic Grids in the Schlenkman et. al. Weather Data

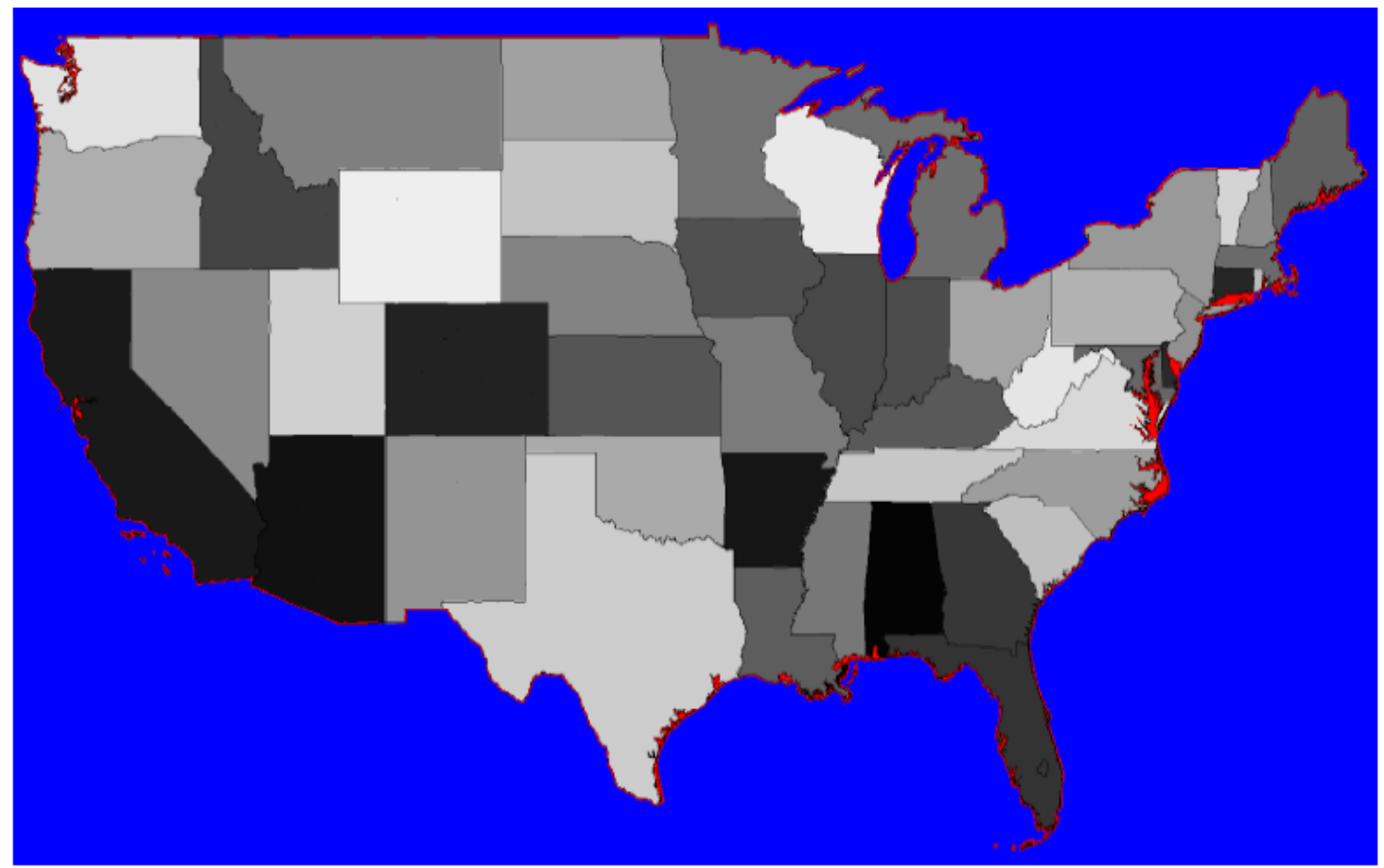

Notes: Link between grid cells in this data and original PRISM data. Grids in our data that have non-missing PRISM values are displayed in grey. Grids which are not in our data but have non-missing PRISM values are are displayed in red. Grids which are not in our data and have missing values in PRISM are displayed in blue. 
Figure 6: Federal Energy Regulatory Commission Geographic Location of the Power Hubs in the United States

This figure was obtained from the Federal Energy Regulatory Commission (www.ferc.gov/oversight). It presents the geographic location of the hubs for electricity forward contract auctions in the U.S. The average dollar value of the near contract over the year 2009 is presented for each hub and the precentage change in this average price from the average over the year 2008.

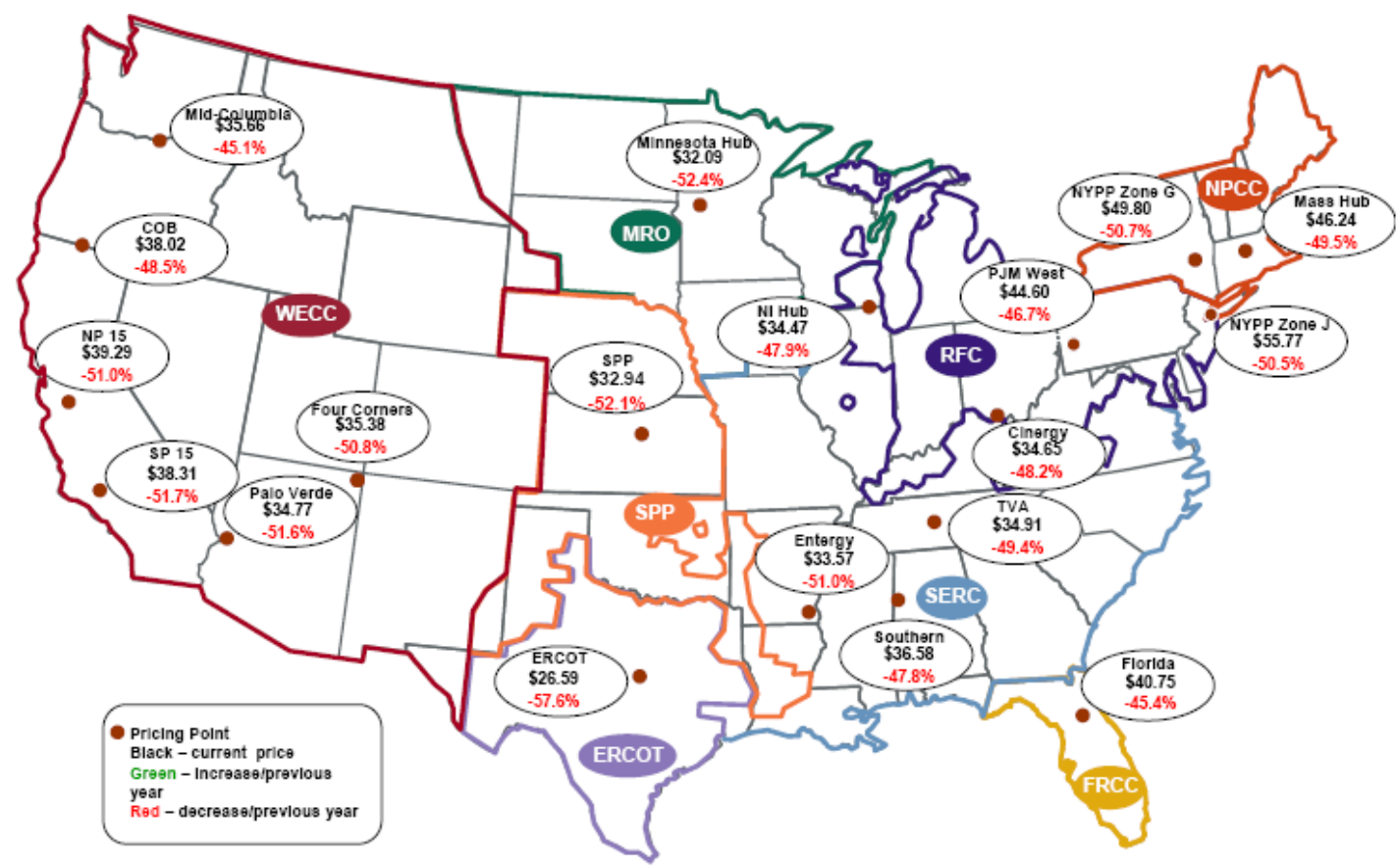

Figure 7: NYMEX Natural Gas Prompt Month (nearest contract) Daily Quotes This figure was computed from daily quotes for NYMEX natural gas prompt month (nearest contract futures contracts.

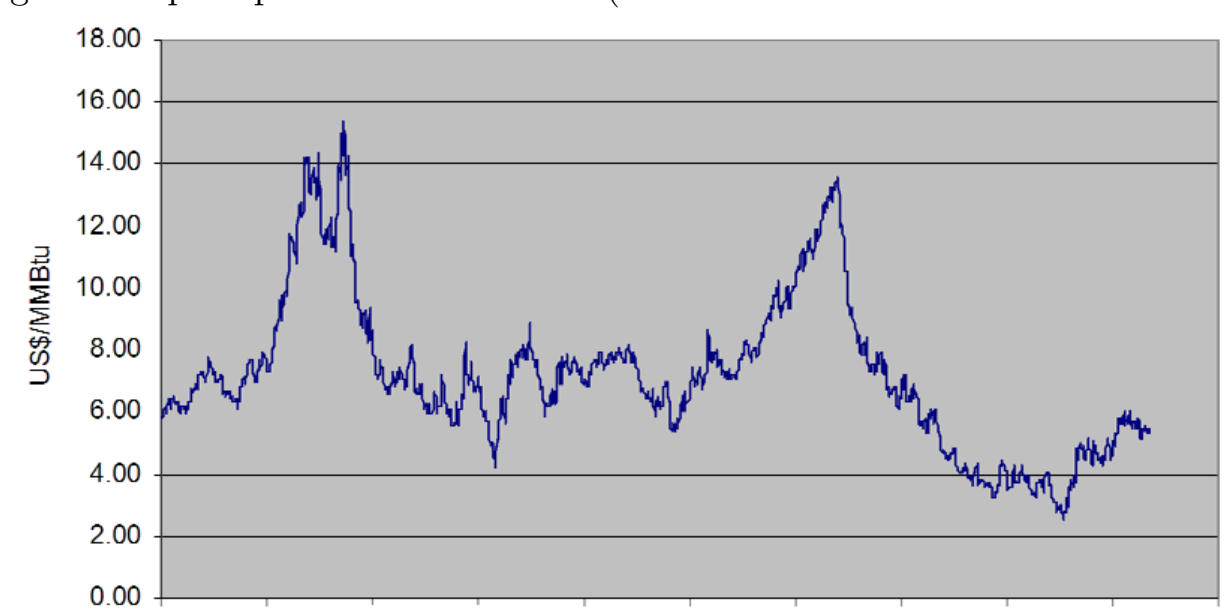

Jan-05 Jul-05 Feb-06 Aug-06 Mar-07 Sep-07 Apr-08 Nov-08 May-09 Dec-09 Jun-10

Trade Date 


\section{References}

Benth, F., A. Cartea, and R. Kiesel, 2008, Pricing forward contracts in power markets by the certainty equivalence principle: Explaining the sign of the market risk price premium, Journal of Banking and Finance 32, 2006-2021.

Benth, F. E., S. Koekebakker, and F. Ollmar, 2007, Extracting and applying smooth forward curves from average-based commodity contracts with seasonal variation, Journal of Derivatives 15, 52-66.

Geman, H., and A. Roncoroni, 2006, Understanding the fine structure of electricity prices, Journal of Business 79, 1225-1261.

Grenadier, S. R., 2005, An equilibrium analysis of real estate leases, Journal of Business 78, $1173-1214$.

Plazzi, A., W. Torous, and R. Valkanov, 2010, Expected returns and hte expected growth in rents of commercial real estate, Review of Financial Studies 23, 3469-3519.

Riedhauser, C., 2000, A no-arbitrage forward commodity curve, Working paper, Pacific Gas and Electric Company.

Wheaton, W. C., and R. Torto, 1994, Office rent indices and their behavior over time, Journal of Urban Economics 35, 121-139. 